\title{
Paridade e desenvolvimento ovariano de Ochlerotatus scapularis (Diptera Culicidae) em condições de laboratório e de campo na região do Vale do Ribeira, São Paulo, Brasil
}

Juliana Telles de Deus

Dissertação apresentada ao Programa de Pós-Graduação em Saúde Pública da Faculdade de Saúde Pública da Universidade de São Paulo para obtenção do título de Mestre em Saúde Pública.

Área de Concentração: Epidemiologia Orientadora: Profa. Dra. Iná Kakitani

\section{São Paulo}

2005 


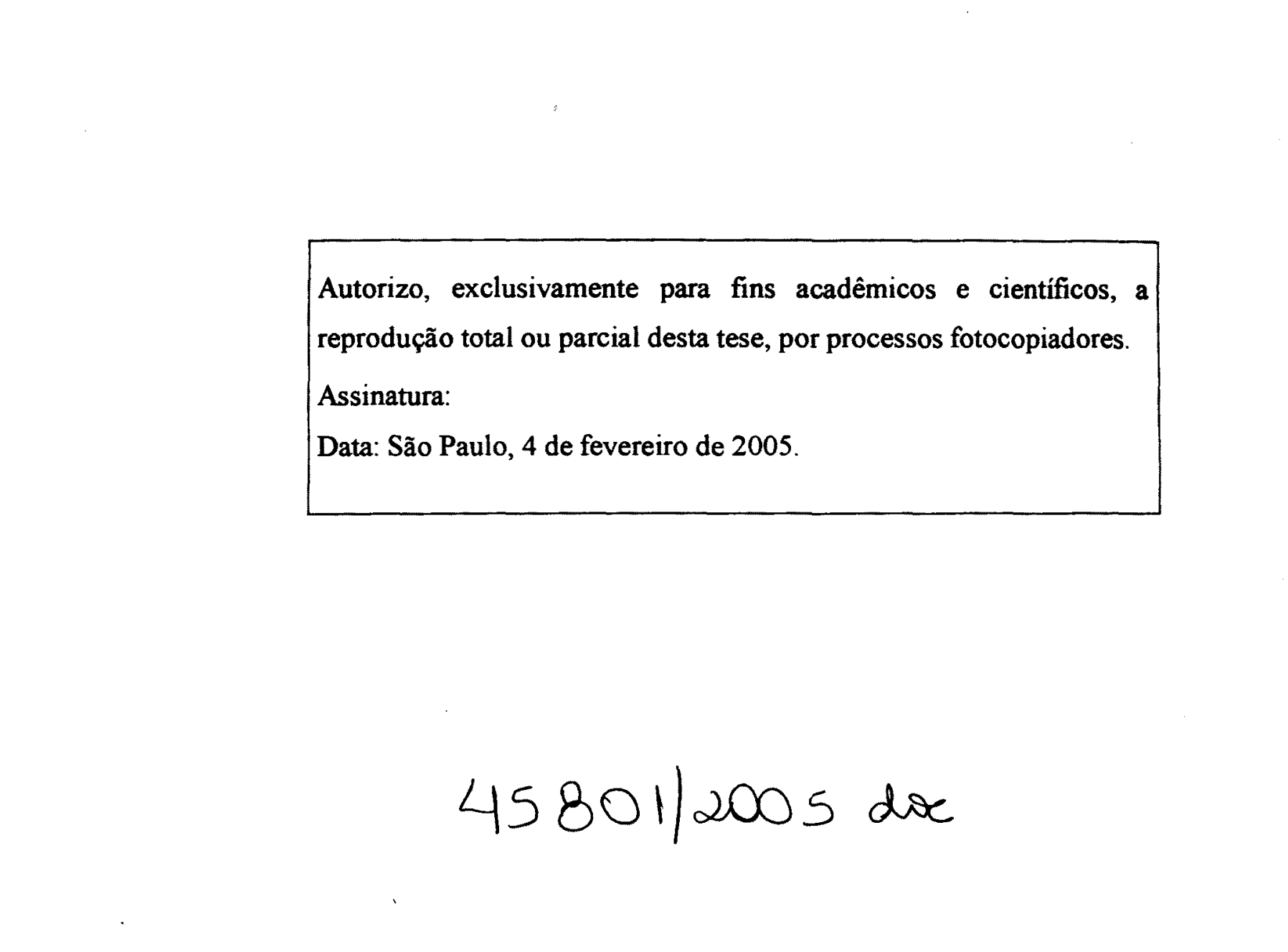


Aos Meus Pais

À minha avó Geny

Com Carinho 


\section{AGRADECIMENTOS}

À Professora Dra. Iná Kakitani, pela orientação e dedicação na realização deste trabalho com o qual espero ter contribuído (mesmo de forma singela) a continuidade da sua linha de pesquisa.

Ao membro da banca examinadora da qualificação Professor Catedrático Oswaldo Paulo Forattini, por valiosas sugestões e pela inspiração que incutiu em mim na escolha da espécie estudada, quando se referiu a ela com tanto entusiasmo. Aos membros da banca examinadora. Professor Livre Docente Délsio Natal e Dra. Regiane Maria Tironi de Menezes, pelas correções preciosas. Com os quais tenho muito a aprender.

À equipe de campo do posto de Pariquiera-Açu, Chico, Décio, Jair, Luís, Roberto e Ruy, pelo empenho em dias de sol e chuva.

Aos funcionários do laboratório da Faculdade de Saúde Pública, Aristides Fernandes, Justiniano Cunha e Rosa Sá, pelo auxílio na criação dos mosquitos e, principalmente, pelo apoio em diversas circunstâncias, durante os 3 anos de trabalho. Ao Ari, também, pelas aulas impagáveis de identificação de mosquitos.

À Dra. Rosa Maria Tubaki, pesquisadora que me iniciou no estudo dos culicideos, com muita paciência e préstimo. Ao Dr. Cláudio Casanova e ao Dr. Ismael Paulino da Costa, por despertar em mim o gosto pelo trabalho de campo. Não poderia deixar de agradecer também a Dra. Edna Clara Tucci que me acolheu e mostrou parte do mundo bonito dos insetos.

À bióloga da FSP e aluna de doutorado Márcia Bicudo de Paula, pelas importantes considerações, sempre encontrando um tempo para ajudar.

Às amigas da época do laboratório da Sucen e de sempre, Andréa Stangarlin, Cidinha, Márcia Gutierrez (Marcinha) e Renata Ramos (BB), pela torcida e afeto demonstrados. 
Aos amigos, cada qual com suas singularidades, que muito me ajudaram: André Consone (e sua autenticidade), Camila Talassi (objetividade), Cássia Cândido (alegria contagiante), Cintia Galina (amiga pra toda a vida), Daniel Wainstein (de olhar sempre gentil), Flávia Luna (correta e leal), Igor (carinhoso), Ivan (sempre com algo bom a dizer), Izilda (delicadeza), Kátia Iwata (agitada e disposta), Lígia Serpa (observadora), Lu Crê (espontânea), Maira (com muita paciência), Marcelo Sciarretta (companheiro desta jornada), Márcio Vitiello (amigão pra todas as horas), Míriam Torrigo (Miroca, menina estudiosa que me trouxe a FSP), Odete (fé na vida), Rita de Cássia (lutadora), Rogério (amigo dos bons), Rosana (moça pra cima), Thais Brandini (pelo auxílio de muitas horas) e Thaís Cândido (Thá, colorindo a vida de rosa).

Agradeço também à amiga Helene Mariko Ueno (Lê) pela amabilidade e generosas contribuiçð̃es, incluindo a confeç̧ão do Summary deste trabalho. Ao Luís Eduardo Castello Branco, pela correção ortográfica e amizade.

Ao Daniel Flores, pela atenção e também pelas revelações de parte das fotos. À Dora, por suas doces palavras. Ao Rodrigo Sportello, que me socorreu em momentos cruciais. $\grave{A}$ Maria Lúcia e demais funcionários da biblioteca da FSP, o meu agradecimento.

Aos familiares, em especial aos meus pais, Newton de Deus e Lídice Telles de Deus pelo amor, apoio e acima de tudo compreensão! Ao meu irmão Ricardo, exemplo para mim por várias razões, desde a seriedade ao trabalho até o bom humor com que leva a vida. Agradeço também à Adriana Maria Pachioni por todo o carinho, à tia Cristina Telles pelo zelo de sempre e ao Dênis (o preferido da vó e da prima) pelo incentivo. E, principalmente, à querida vovó Geny, que tanto rezou por esta neta! Aos demais familiares não citados mas não esquecidos desta grande família, o meu muitíssimo obrigada.

Ao Conselho Nacional de Pesquisa (CNPq), pelo apoio financeiro durante parte da execução deste trabalho. Esta dissertação teve apoio financeiro da FAPESP (Fundação de Amparo à Pesquisa do Estado de São Paulo) - Projeto Temático nº 99/10517-1 


\section{RESUMO}

Deus JT de. Paridade e desenvolvimento ovariano de Ochlerotatus scapularis (Diptera Culicidae) em condições de laboratório e de campo na região do Vale do Ribeira. São Paulo, Brasil. São Paulo; 2004. [Dissertação de Mestrado - Faculdade de Saúde Pública da USP]

Objetivo. Identificar o estado de paridade em fêmeas de Ochlerotatus scapularis em condições de laboratório e campo. Das fêmeas coletadas em campo, determinar o grau de paridade considerando sua importância epidemiológica como possivel transmissor de patógenos. Métodos. $O$ trabalho foi dividido em duas partes: no campo foram realizadas coletas quinzenais no Vale do Ribeira de abril de 2003 a março de 2004, utilizando-se a técnica da aspiração manual. No laboratório, 100 fêmeas (F1) de Ochlerotatus scapularis foram criadas e observadas individualmente anotando-se o número de repastos por elas realizados, duração do ciclo gonotrófico e número de ovos colocados. A observação do estado de paridade e desenvolvimento ovariano foi feita através da dissecção dos ovários de 90 fềmeas, por coleta, e de todas as fềmeas criadas. Resultados. Das 100 fềmeas mantidas em laboratório e dissecadas, o diagnóstico de condição de paridade conferiu com os resultados constatados em $55 \%$ dos casos, sendo subestimados em 37\% e superestimados em 2\%. Ainda em laboratório, de 106 ciclos gonotróficos completados, cerca de $55 \%$ das fêmeas necessitaram de mais de um repasto sangüineo antes de ovipor, indicando uma possível discordância gonotrófica para a espécie. Sob condições laboratoriais observou-se uma sobrevivência de até 26 dias para a espécie. Foram dissecadas 1180 fêmeas de Oc. scapularis do campo: $418(35,4 \%)$ foram consideradas nuliparas, $655(55,5 \%)$ uníparas, $46(3,9 \%)$ como bíparas e 61 $(5,2 \%)$ não puderam ser avaliadas. Foi observado que 90 fêmeas apresentavam-se na fase III-V de Christopher e Mer, reforçando a hipótese de discordância gonotrófica. A variável estado de paridade variou ao longo do ano. Conclusões: Observando fêmeas de Oc. scapularis no campo e laboratório, confirmamos a hipótese de discordância gonotrófica.

Descritores: Paridade, desenvolvimento ovariano, Ochlerotatus scapularis. 


\section{SUMMARY}

Deus JT de. Paridade e desenvolvimento ovariano de Ochlerotatus scapularis (Diptera Culicidae) em condições de laboratório de campo na região do Vale do Ribeira. São Paulo, Brazil. [Parity and ovarian development of Ochlerotatus scapularis (Diptera: Culicidae) in laboratory and field conditions in Vale do Ribeira region. Sao Paulo, Brazil]. Sao Paulo (BR); 2004. [M. Sc. Dissertation - Faculdade de Saúde Pública da Universidade de São Paulo, Brazil].

Objective. Identify the parity status of Ochlerotatus scapularis females in laboratory and field conditions. Regarding the field females, to determine the parity degree, considering this species epidemiologic importance as a possible pathogens vector. Methods. The research has two parts: field collections every 15 days were carried out in Vale do Ribeira from April 2003 to March 2004, using a hand-held aspirator. In laboratory, 100 Ochlerotatus scapularis $F_{1}$, females were obtained and followed up individually, reporting the number of blood meals, the lentgh of gonotrophic cycle and survival. The parity status and the ovarian development were observed through ovarium dissection of 90 field females for each collection and all females reared in laboratory. Results. The parity status diagnoses of the 100 females reared in laboratory and dissecated were according to $55 \%$ of the oviposition data, were underestimated in $37 \%$ and overestimated in 2\%. Also in the laboratory, 106 gonotrophic cycles were completed, around $55 \%$ of females needed more than one blood meal before laying eggs. Under laboratory conditions, the females survived for up to 26 days. 1180 field females of Ochlerotatus scapularis were dissecated: 418 (35,4\%) nulliparous, 655 (55,5\%) uniparous, $46(3,9 \%)$ biparous and $61(5,2 \%)$ could not be evaluated. We observed that 90 field females were found in Christopher and Mer phase III-V. Conclusions. Based on field and laboratory observations on Ochlerotarus scapularis females, we confirm the gonotrophic discordance hypothesis. The qualitative variable of parity status differed significantly throughout the year.

Descriptors. Parity. Ovarian Development. Ochlerotatus scapularis 


\section{ÍNDICE}

1. INTRODUÇÃO

1.1 Determinação da idade de culicídeos 1

1.2 Diagnóstico de paridade segundo Escola Clássica e Escola Nova 3

1.3 Ochlerotatus scapularis

2. OBJETIVOS 10

$\begin{array}{ll}2.1 \text { Objetivo geral } & 10\end{array}$

$\begin{array}{ll}2.2 \text { Objetivos específicos } & 10\end{array}$

3. MATERIAL E MÉTODOS 11

$\begin{array}{ll}3.1 \text { Laboratório } & 11\end{array}$

3.1.1 Técnica de disseç̧ão dos ovários 11

$\begin{array}{ll}3.2 \text { Campo } & 14\end{array}$

3.2.1 Área de estudo $\quad 14$

$\begin{array}{ll}\text { 3.2.2 Captura } & 17\end{array}$

$\begin{array}{ll}3.3 \text { Análise de dados } & 19\end{array}$

4. RESULTADOS 20

4.1 Laboratório 20

4.1.1 Frequência de oogênese abortiva e normal em condições de laboratório20

4.1.2 Frequêencia de oviposição e média de ovos colocados 24

4.1.3 Verificação do diagnóstico de condição de paridade 26

4.1.4 Relação entre repasto sangüineo e ciclo gonotrófico 27

4.1.5 Intervalo entre repastos 29

4.1.6 Sobrevivência de fêmeas de Ochlerotatus scapularis 29

$\begin{array}{ll}4.2 \text { Campo } & 31\end{array}$

5. DISCUSSÃO 33

5.1 Freqüência de oogênese normal e abortiva 34

5.2 Número de oviposições e média de ovos colocados 36

$\begin{array}{ll}5.3 \text { Diagnóstico e condição de paridade } & 37\end{array}$

5.4 Relação entre repasto sangüíneo e ciclo gonotrófico 39 
5.6 Sobrevivência

6. CONCLUSŌES 42

7. CONSIDERAÇÕES FINAIS 43

8. REFERÊNCIAS

\section{ANEXOS}

Anexo 1 - Tabelas com os dados de laboratório

A1

Anexo 2 - Procedimento com o material de campo 


\section{INTRODUÇÃO}

\subsection{Determinaçăo da idade de culicídeos}

A determinação da idade de fềmeas de insetos não é interesse puramente do estudo ecológico, trata-se de um parâmetro importante para estimar o indice de mortalidade da população. Quando tratamos de insetos vetores de doenças, tal dado alcança maior relevância. A longevidade das fềmeas de mosquito é fator que influencia a sua eficácia epidemiológica, assim quanto maior sua idade fisiológica, maior é a oportunidade do mosquito entrar em contato com o agente infeccioso (FORATTINI $1962 ; 2002)$.

O estudo da composição etária é importante para a avaliação da capacidade vetora de culicideos que está diretamente ligada à densidade, proporção de picadas, antropofilia e sobrevivência da população. Sua sobrevivência pode ser estimada por meio da determinação da paridade e dos ciclos gonotróficos desenvolvidos pelas fềmeas. Essas informações são importantes para se ter uma estimativa da oportunidade de contato com o agente etiológico (KLOWDEN e BRIEGEL 1994). Entende-se por ciclo gonotrófico o periodo que vai da procura pelo repasto sangüineo, até a oviposição (FORATTINI 1962).

A estimativa da idade dos Culicidae pode seguir critérios como a avaliação do desgaste das asas (PERRY 1912 apud FORATTINI 1962), porem, sabe-se que influências externas atuam na descamação do inseto, o que então prejudica a eficiência 
desse método. Outros métodos também podem ser utilizados na determinação da idade fisiológica desses dípteros, conforme coloca CHARLWOOD et al. (1980): presença de ovos retidos, presença de ácaros fixados às fêmeas, tamanho da ampola dos ovários, mas o método mais eficiente se refere ao exame do aparelho reprodutor feminino.

$\mathrm{O}$ aparelho reprodutor das fêmeas, ao longo da oogênese, sofre modificações irreversíveis que podem indicar a sua idade fisiológica. $O$ ovário possui uma rede de traquéias e traquéolas, estas quando enoveladas, indicam a condição de fêmea nulipara. Com o início da oogênese, os ovários aumentam em tamanho e o enovelado vai se distendendo e se desfazendo de forma irreversivel, apresentando-se totalmente desenrolado ao fim da primeira oogênese, constituindo uma rede de finas traquéolas (DETINOVA 1962). Entretanto, há evidências de uma condição intermediária, onde poucos filamentos apresentam-se desenrolados (KARDOS e BELLAMY, 1961). De qualquer maneira, este método permite distinguir a proporção de fêmeas oniparas na população, porém não distingue o grau de paridade (FORATTINI 2002). A observação das traquéolas é muito utilizada quando se pretende dissecar número grande de insetos, porém não pode ser utilizada para observar a estrutura da idade cronológica de uma população (CHARLWOOD et al. 1980).

Já o método de Polovodova, descrito por Gillies e Wilkes (CHARLWOOD et al. 1980), consiste na observação das dilatações foliculares no pedicelo ovariolar formadas após cada postura e, assim, podemos associar o número de dilatações ao seu grau de paridade. 


\subsection{Diagnóstico de paridade segundo Escola Clássica e Escola Nova}

A relação entre o estado de paridade de culicídeos e seu contato com o hospedeiro gerou o que se chama de taxa para diagnósticos de paridade, que é muito útil na epidemiologia de algumas doenças (FOX e BRUST 1994).

Após a oviposição, o ovariolo apresenta seu tubo folicular distendido com paredes frouxas, sendo então chamado de saco ovariolar. As Escolas Clássica e Nova discordam quanto à interpretação deste saco ovariolar.

Segundo premissa da Escola Clássica, originada por Polovodova (CHARLWOOD et al. 1980), o saco ovariolar é, em poucas horas ou dias, contraído formando um vestígio de sua existência, representado por uma dilatação folicular que permanece mesmo com a postura subseqüentes. Assim, de acordo com a interpretação desta Escola, contando-se o número de dilatações ocorridas num mesmo ovariolo, chega-se ao número de ciclos ovarianos completados por aquela fêmea. Quando apenas uma dilatação é encontrada, considera-se a fêmea como unípara. Havendo duas dilatações, esta será bípara e assim por diante (FORATTINI 2002).

Para a Escola Nova, as dilatações só ocorrem quando a oogênese for abortiva, ou seja, a ovulação resulta somente na formação de um saco terminal. Para ser considerado como "ovariolo diagnóstico", assim chamado por FOX e BRUST (1994), o ovariolo precisa cumprir oogêneses abortivas em cada ciclo. Portanto, se as oogêneses forem todas normais, o ovaríolo apresentará um saco ovariolar ou vestígio deste, e esta fêmea será considerada unípara, mesmo se tiver realizado múltiplas oviposições. Neste 
caso, se o pesquisador fosse considerar a interpretação da Escola Clássica, poderia avaliar como ausência de fêmeas multíparas na população, o que não corresponderia à realidade. Quanto mais ciclos normais, a fềmea tiver realizado, menor a proporção de ovariolos diagnósticos (que poderiam ser indicadores de ciclos gonotróficos) (HOC e CHARLWOOD 1990; FOX e BRUST 1994).

Ambas as Escolas concordam sobre a existência da oogênese abortiva. Ainda para a Escola Nova, o diagnóstico para fêmeas que apresentam saco ovariolar é de uniparidade, considerando que ela desenvolveu uma oogênese normal, ou seja, que resultou em oviposição. As dilatações são consideradas de natureza abortiva, representando a degeneração folicular; quando se observa uma dilatação e saco ovariolar, a fêmea é considerada bípara (pois duas oogêneses foram realizadas) (FORATTINI 2002).

Apesar das dilatações ovariolares representarem (para a Escola Nova) oogêneses abortivas, este resultado interessa no estudo da capacidade vetora. FOX e BRUST (1994) consideram que, ocorrendo uma oogênese normal ou abortiva, houve pelo menos um repasto sangüineo, representando um ciclo - é o que denominaram “ovariolo diagnóstico", referindo-se ao ovariolo que apresenta alterações que permitam estimar o estado de paridade da fềmea, seja formação do saco ovariolar ou dilatação folicular. Num segundo ciclo, a avaliação só valerá para os ovaríolos com oogêneses abortivas, assim, todos os ovariolos devem ser examinados para o diagnóstico ovariolar.

O método de Polovodova exige destreza para a dissecção. HOC e CHARLWOOD (1990) descreveram a técnica da injeção de óleo no oviduto comum, que provoca o intumescimento do ovário e conseqüentemente torna os ovariolos mais 
evidentes. A técnica visa a facilitar a observação das dilatações ovariolares. Neste trabalho, os autores identificaram quatro tipos de ovaríolos. O primeiro com oogênese normal, apresentando saco ovariolar; o segundo apresenta dilatação distal e saco ovariolar; o terceiro mostrando dilatação basal onde somente dilatações foram encontradas (sem vestígio de saco ovariolar), o que consideraram como tendo havido degeneração em todos os ciclos; por último, observaram o chamado ovaríolo anão ("dwarf ovariole") descrito anteriormente por DETINOVA (1962) e que SOKOLOVA (1994) chamou de ovaríolos diminutos ("diminutive ovarioles"). Os ovariolos anões possuem folículos não desenvolvidos completamente, podendo ser confundidos com dilatações, porém se distingue dos outros pelo tamanho pequeno e através do comprimento do pedicelo entre estas "dilatações".

SERVICE (1993) testou sem sucesso a injeção de outros óleos no oviduto ovariolar na tentativa de diminuir as dificuldades da prática. Usou para isso a mesma espécie (Aedes cantans) que HOC e CHARLWOOD (1990) utilizaram em seu trabalho.

\subsection{Ochlerotatus scapularis}

O subgênero Ochlerotatus foi elevado a gênero por REINERT (2000), que se baseou nas características morfológicas da genitália masculina e feminina, entre outras. As abreviações das espécies de culicídeos seguiram critérios revisados por REINERT (2001). 
Oc. scapularis possui ampla distribuição no continente americano, com predominância neotropical, e maior freqüência na América do Sul (CONSOLI e LOURENÇO-DE-OLIVEIRA 1994; FORATTINI 2002). Cria-se em coleções líquidas no solo, temporárias ou semipermanentes, formadas após chuvas. Além de poças de água doce, também podem servir como criadouros escavações ocorridas em pedras (FORATTINI 2002).

CASANOVA (1994) e CASANOVA e PRADO (2002) mostraram a relação direta entre excedente hídrico e formação de criadouros propícios ao desenvolvimento completo dos Oc. scapularis e a ausência de criadouros em períodos de déficit hídrico. As populações desta espécie podem então ser controladas, em parte, naturalmente pela ação conjunta da ação do tempo e a presença de predadores nos criadouros naturais. Ainda sobre o desenvolvimento das formas imaturas, a espécie foi encontrada em recipientes artificiais como latas e plásticos abandonados (SILVA e MENEZES 1996; FORATTINI et al. 1997).

A espécie apresenta, segundo KAKITANI et al. (2003), considerável densidade com pico de atividade no pós-crepúsculo vespertino até às 20h. Após este horário, ocorre uma diminuição em quantidade, e apresentando ligeiro aumento novamente no précrepúsculo matutino (FORATTINI e GOMES 1988, FORATTINI et al. 2000).

FORATTINI et al. (1986) mencionaram a presença constante de Oc. scapularis no Vale do Ribeira, em ambiente antrópico. Esta espécie demonstra a adaptação ao ambiente extraflorestal artificialmente modificado. A hipótese de adaptação secundária dessa espécie ao ambiente antrópico ficou confirmada ao se encontrar criadouros 
artificiais dos mesmos nos, Municípios de Ilha Comprida e de Pariquera-Açu (FORATTINI et al 1997). Tal proximidade do mosquito com a população humana pode gerar, segundo FORATTINI et al. (1986), “implicações epidemiológicas na transmissão de agentes infecciosos à população humana". Tal afirmação é recolocada pelo autor e colaboradores que constataram a presença (da população) de Oc. scapularis em núcleo habitado, fazendo ressalva sobre o "interesse epidemiológico no caso das arboviroses" (FORATTINI et al. 2000).

As fêmeas, vorazes, tendem a se alimentar de mamíferos de grande porte incluindo o homem (FORATTINI 2002), esta tendência foi reforçada por (GOMES et al. 2003) que verificaram a predominância de sangue de gado e cachorros em fêmeas ingurgitadas. No entanto, há evidências de repastos mistos em homem animais sendo que para a espécie supracitada, 7 reações mistas foram constatadas. A alimentação eclética pode ser fator importante, na transmissão de agentes infecciosos, sugerindo importância epidemiológica (FORATTINI et al. 1987).

Com o surto epidêmico de Encefalite Rocio em 1975 e 1976, a Região do Vale do Ribeira despertou interesse para o estudo da doença, sendo que mais de mil pessoas foram acometidas e houve uma centena de óbitos (IVERSON 1989). FORATTINI (1978b) levantou a hipótese da participação dos mosquitos Culicidae na transmissão domiciliar, sendo que nestes ambientes alterados com registros de casos clínicos, $O c$. scapularis e Culex (Melanoconion) sp foram os representantes mais abundantes.

A competência vetora do Oc. scapularis para o virus Rocio (ROC) foi testada por MTCHELL et al. (1986). Os autores verificaram que Psorophora ferox e Oc. 
scapularis de regiões endêmicas do Estado de São Paulo foram suscetíveis para a infecção do virus e capazes de transmiti-lo, se passarem pelo periodo apropriado de incubação após picada.

Considerando o comportamento da população de Oc. scapularis na região epidêmica, e os resultados obtidos em infecção experimental, FORATTINI et al. (1995) concluíram a capacidade epidemiológica vetora para o vírus ROC. Apesar do último caso clínico da doença em humano ter ocorrido em 1976, IVERSON et al. (1989) sugerem que o vírus continuou a circular entre a população humana na região, este dado foi confirmado num inquérito soroepidemiológico, publicado por ROMANO-LIEBER e IVERSON (2000), quando observaram a presença de anticorpos para este e outros arbovírus em moradores de reserva ecológica no Vale do Ribeira.

Oc. scapularis também já foi incriminado como vetor de Wuchereria bancrofti no Estado de Santa Catarina. É considerado vetor primário da Dirofilaria immitis no Sudeste do Brasil, já que foi encontrado naturalmente infectado em regiões do Estado do Rio de Janeiro (LOURENÇO-DE-OLIVEIRA e DEANE 1995, LABARHE et al. 1998). Este filarídeo acomete populações de cães domésticos e outros mamíferos, sendo a dirofilariose considerada uma zoonose emergente (CONSOLI e LOURENÇO-DEOLIVEIRA 1994; AHID e LOURENÇO-DE-OLIVEIRA 1999; FORATTINI 2002,).

MENEZES (2002) encontrou fềmeas de Oc. scapularis nas fases III, IV e V do desenvolvimento folicular com o intestino médio totalmente cheio de sangue vermelho representando, segundo a autora, um indício de discordância gonotrófica, indicando que essas populações podem realizar mais de um repasto sangüíneo antes de completar o 
ciclo gonotrófico. Um número maior de repastos sangüíneos significa maior oportunidade de contato entre mosquito e o arbovírus. 


\section{OBJETIVOS}

\subsection{Objetivo Geral}

Identificar o estado de paridade em fêmeas de Oc. scapularis em condições de laboratório e campo. Das fêmeas coletadas em campo, determinar o grau de paridade, considerando sua importância epidemiológica.

\subsection{Objetivos Específicos}

Em laboratório:

- avaliar o diagnóstico da paridade com as observações feitas em laboratório;

- verificar a ocorrência ou não da concordância gonotrófica em Oc. scapularis;

- avaliar a sobrevivência de fêmeas de Oc. scapularis.

Dados do campo:

- verificar a ocorrência de oogênese abortiva e normal de fềmeas de Oc. scapularis segundo a interpretação da Escola Nova. 


\section{MATERIAL E MÉTODOS}

O trabalho foi dividido em duas etapas, sendo que uma parte foi realizada no laboratório de Culicidologia da Faculdade de Saúde Pública da Universidade de São Paulo e a outra no campo em três localidades escolhidas no Vale do Ribeira.

\subsection{Laboratório}

\subsubsection{Técnica de dissecção dos ovários}

Para se conhecer o desenvolvimento dos folículos ovarianos e paridade das fêmeas, foi adotada a técnica de Polovodova (DETINOVA 1962, 1968). Esta consiste na dissecção do abdômen do mosquito e separação dos ovários, que são distendidos a fím de observar os ovariolos individualmente.

As fêmeas já individualizadas por Borrel (tubo de vidro com $9,5 \mathrm{~cm}$ de altura $\mathrm{x}$ $4 \mathrm{~cm}$ de diâmetro) eram anestesiadas com éter, colocadas sob lâmina e, com o auxílio de dois estiletes e lupa seguia-se primeiramente a separação do abdômen do resto do corpo, este era descartado. Sobre uma gota d'água as estruturas eram pinçadas por meio do último esternito. Visualizados os dois ovários, estes eram separados das demais estruturas.

Em seguida os ovários eram distendidos até que todos os ovariolos estivessem separados. Este processo não poderia demorar mais que alguns minutos, pois, do contrário, as estruturas ressecariam na lâmina, prejudicando a observação. 
Depois deste procedimento, a lâmina era levada ao microscópio óptico onde era observada com um aumento de 400 vezes. Todos os ovariolos foram analisados e diagnosticados segundo a Escola Nova, ou seja, encontrando-se um ou mais ovaríolo com saco ovariolar, esta fêmea era considerada como unipara. Quando encontrada uma dilatação e um saco ovariolar no mesmo ovariolo, a fêmea era então considerada como bípara (com uma oogênese normal e uma abortiva). Após a anotação do resultado, a lâmina era descartada (ou fotografada e arquivada).

Fêmeas de Oc. scapularis capturadas em Cananéia foram mantidas em laboratório para a obtenção de fềmeas F1. Os mosquitos coletados foram levados ao laboratório e mantidos em gaiolas dentro de estufa à temperatura de $26^{\circ} \mathrm{C}$ a $28^{\circ} \mathrm{C} \mathrm{com}$ umidade relativa (UR) de $80 \%$. As fêmeas eram individualizadas em Borrel preparado com algodão e papel filtro umedecido, sendo depois fechado por uma tela de nylon fina presa com elástico. Foi oferecido a cada fêmea o repasto sangüíneo. Os insetos foram mantidos em estufa com UR de $80 \%$ até a oviposição, após a qual aguardava-se 2 ou 3 dias para o "amadurecimento" dos ovos, quando esses eram colocados em uma placa de gesso úmido com o auxílio de um pincel.

Os ovos ficaram armazenados na placa de gesso até o momento de serem colocados em recipiente plástico $(40 \mathrm{~cm} \times 27 \mathrm{~cm} \times 5 \mathrm{~cm})$ para a eclosão, onde foi adicionada água destilada com cloreto de sódio e alimento para peixe (Tretaminß). $\mathrm{O}$ desenvolvimento dos imaturos era acompanhado diariamente e, a cada dia, separavam-se as pupas que eram levadas às gaiolas (onde foram colocadas anotações sobre a origem dos ovos e idade das pupas). 
Nas gaiolas havia oferta de alimento à base de solução de água e açúcar a 10\%, através de uma "bolota" feita de algodão envolta por gaze.

Assim que os adultos emergiam, aguardavam-se dois dias para isolar as fêmeas em Borrel. A partir da observação dessas fêmeas é que pudemos seguir com a parte laboratorial da pesquisa, com a segurança de trabalharmos com material de origem e idade conhecida.

Os recipientes com as fêmeas foram etiquetados, enumerados, e a elas foi ofertado fonte de sangue para o repasto. As anotações eram feitas diariamente com as seguintes considerações: quando havia se transformado em pupa, data de cada repasto ou a recusa por ele, data de oviposição, número de ovos e morte. Estes dados constam na tabela 1 e quadro 1 (anexo 1).

Ficou estabelecido que o repasto seria oferecido todo o dia até que a fêmea aceitasse o primeiro. Depois seria oferecido dia sim dia não, até a oviposição. Este intervalo se deve à tentativa de evitar o estresse do mosquito. Quando a fêmea ovipusesse, neste mesmo dia já seria oferecido um novo repasto e nos dias seguintes, consecutivamente, até que ela o aceitasse novamente, e assim era feito a cada oviposição e repasto.

Depois de uma oviposição, a fêmea era transferida para um novo Borrel preparado. Desta forma, pudemos contar o número de ovos colocados em cada ciclo.

Assim foi feito com 100 fêmeas de Oc. scapularis até a morte das mesmas. Quando cada uma delas morria, no mesmo dia a fềmea era dissecada para a observação dos folículos ovarianos utilizando-se a técnica descrita anteriormente. 
Esses dados foram utilizados para darmos embasamento à técnica escolhida, já que conhecíamos toda a história reprodutiva das 100 fêmeas estudadas.

\subsection{Campo}

\subsection{1 Área de Estudo}

O estudo foi realizado no Vale do Ribeira, área com cerca de $17.000 \mathrm{~km}^{2}$ que se situa entre $24^{\circ}$ e $25^{\circ} 16^{\prime} \mathrm{S}$, e $46^{\circ} 50^{\prime}$ e $49^{\circ} 20^{\prime} \mathrm{W}$. O clima desta região é tropical superúmido com temperaturas médias entre 18 e $25^{\circ} \mathrm{C}$ e precipitação anual de $1800 \mathrm{~mm}$, atingindo $2000 \mathrm{~mm}$ a $3000 \mathrm{~mm}$ na zona de escarpa da Serra. Possui formação florestal latifoliada tropical úmida na encosta, e floresta perenifólia latifoliada higrófila costeira (FORATTINI 1978a).

Para este estudo, três municípios foram selecionados: Cananéia, Ilha Comprida (Boqueirão Norte), e Pariquera-Açu. A figura 1 mostra a localização dos municípios com suas coordenadas. 


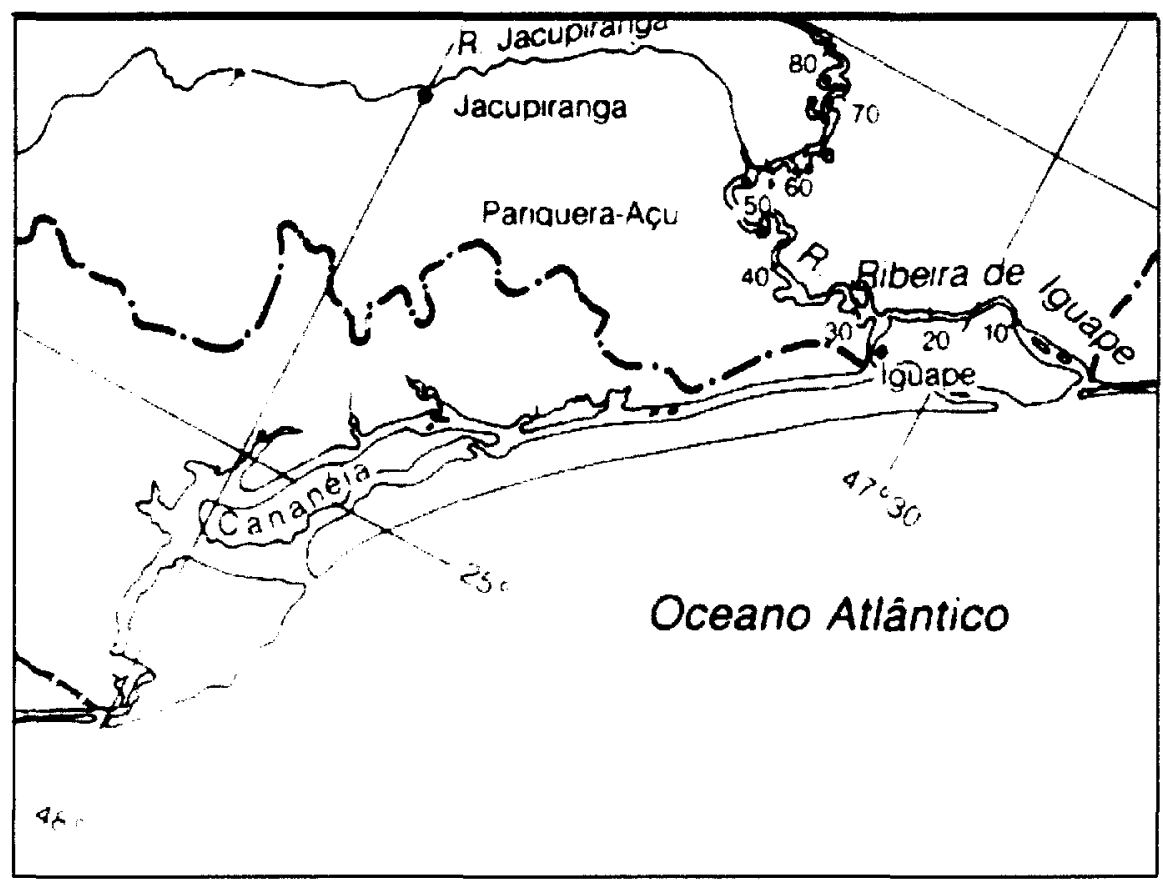

Figura 1: Localização dos três municípios onde foram realizadas as coletas: Cananéia, Ilha Comprida e Pariquera-Açu.

Fonte: Secretaria do Estado do Meio Ambiente (1992).

De acordo com o SEADE (2004), o perfil municipal de Pariquera-Açu em 2004 era de 19.498 habitantes com $70,03 \%$ de taxa de urbanização, numa área de $370 \mathrm{~km}^{2}$. No município de Ilha Comprida, o registro da população foi de 8.017 habitantes, a taxa de urbanização de $100 \%$ e a área com $182 \mathrm{~km}^{2}$. Em Cananéia, neste mesmo ano, foi estimada a população de 13.606 habitantes, $84,82 \%$ de taxa de urbanização e área de $1.272 \mathrm{~km}^{2}$.

As três localidades apresentam, como característica, acentuada alteração do ambiente primitivo com casas situadas em locais abertos e próximos a matas residuais. 
No município de Pariquera-Açu, localiza-se o posto da USP onde o material era triado e muitas vezes dissecado.

Em cada localidade as coletas aconteceram no peridomicílio, caracterizado por terrenos propícios à formação de poças, que servem de criadouro para as formas imaturas de Oc. scapularis e outras espécies. Esses criadouros, de tamanhos variados e rodeados por gramíneas, formavam-se em depressões no solo após a ocorrência de chuvas, e por isso são chamados de criadouros temporários (FORATTINI 2002). A figura 2 ilustra o criadouro formado após chuva, próximo a um dos pontos de captura dos insetos adultos.

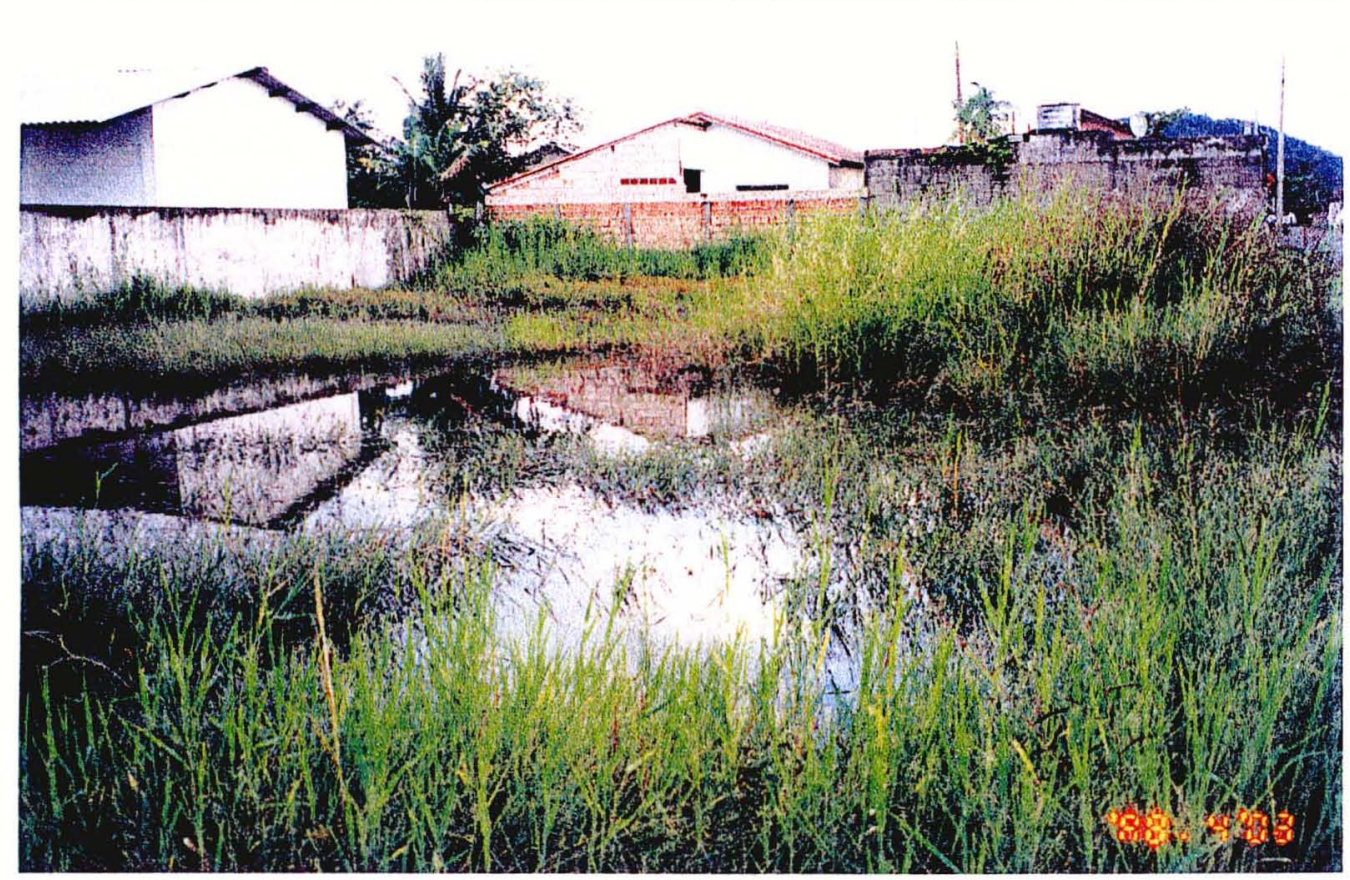

Figura 2: Criadouro temporário de Oc. scapularis. Cananéia, abril de 2003. 


\subsubsection{Captura}

As capturas dos culicídeos adultos foram realizadas quinzenalmente no período estipulado das 17:00 às 20:00 horas (fracionado de hora em hora) baseando-se no comportamento da espécie estudada que, apesar de apresentar hábitos diurnos, possui picos durante e logo após o crepúsculo vespertino (FORATTINI et al. 1981; KAKITANI et al. 2003).

Foi utilizada a técnica da Aspiração Manual ou Aspiração Menor, que consiste na utilização de um aspirador mecânico NM, aparelho movido à pilha de 6 volts pelo qual os mosquitos adultos são capturados no instante em que se aproximam do coletor (SERVICE 1993; KAKITANI 2003). Optou-se por esta técnica porque nos interessava a captura de fêmeas que eram atraídas, ou seja, buscavam fonte sangüínea para realizar o repasto, considerado este um dado importante para observarmos se há ou não a concordância gonotrófica da espécie. Os mosquitos eram capturados vivos antes de exercer a hematofagia. A figura 3 mostra a técnica sendo aplicada no município de Cananéia. No mesmo horário, dois outros coletores realizavam a captura em dois outros pontos, na mesma localidade. 


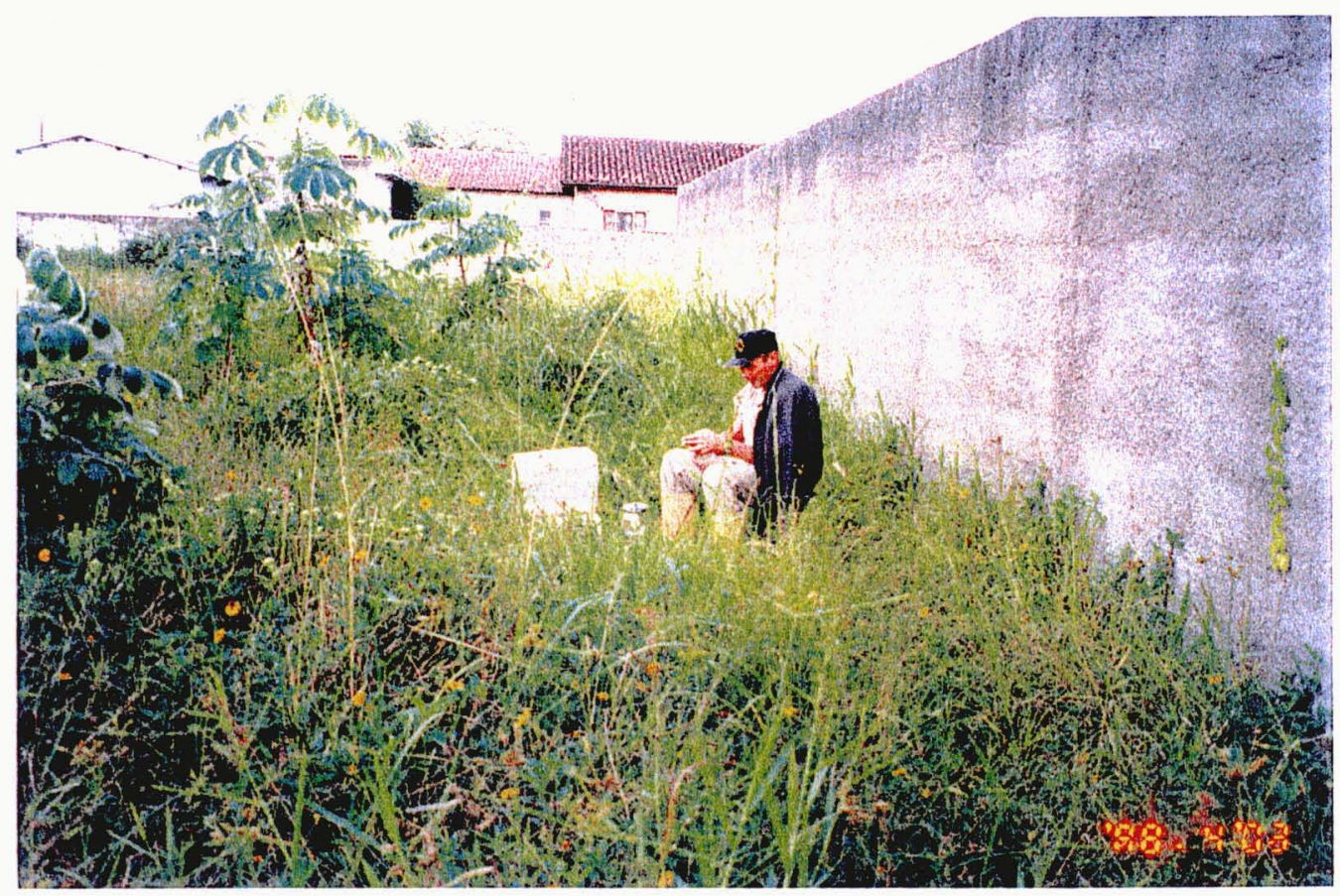

Figura 3: Técnica da aspiração manual ou aspiração menor. Cananéia, abril de 2003

Em cada localidade foram estabelecidos três pontos de coleta, onde as capturas ocorreram simultaneamente, ficando designado para cada ponto, um coletor com um aspirador e três gaiolas, uma para cada hora, nas quais o material coletado era depositado.

Todos os mosquitos, sem distinção de espécie, eram colocados na gaiola onde eram mantidos vivos. Terminada a coleta, o material era levado ao laboratório do posto de Pariquera-Açu, protegidos com panos úmidos, procurando manter a umidade adequada para os mosquitos.

No laboratório de Pariquera-Açu, era feita a triagem dos mosquitos, separandose dez fêmeas de Oc. scapularis por horário (dos três pontos de coleta), que eram colocadas individualmente em Borrel. A separação das fêmeas era feita de forma 
aleatória, isto é, não probabilística. Desta forma espera-se que a localidade tenha sido bem explorada na coleta. Este processo acontecia com os culicídeos vivos através de observação das características morfológicas da espécie. Esta triagem é mostrado na figura 4 (Anexo 2).

Assim, trinta fềmeas eram separadas por localidade (dez por horário). A razão desses números se deve à capacidade operacional para dissecar e observar os ovários e ovariolos dos mosquitos, tarefa essa que exige um trabalho minucioso.

Cada Borrel era previamente preparado, com uma camada de algodão e papel filtro embebido em água destilada em seu fundo. Depois que a fêmea era colocada neste recipiente, este era coberto por uma malha fina de nylon presa com elástico. $O$ material era então disposto em caixa de isopor com papel umedecido ao fundo, até o momento da disseç̧ão.

\subsection{Análise de dados}

Os resultados obtidos em laboratório foram organizados em banco de dados montado com o programa Excel para Windows, observando-se as percentagens e freqüências dos dados. 


\section{RESULTADOS}

\subsection{Laboratório}

Foram dissecadas 100 fêmeas F1 de Oc. scapularis obtidas em laboratório. As anotações completas sobre a vida de cada uma, assim como as observações dos estados de paridades estão na tabela 1 (Anexo 1).

\subsubsection{Freqüência de oogênese abortiva e normal em condições de laboratório}

Entre as 100 fêmeas criadas, 39 foram consideradas nulíparas, 54 uníparas, uma bípara e seis sem condições de avaliação. Não foi encontrado nenhum exemplar multíparo (com mais de duas dilatações no pedicelo ovariolar).

Das 39 fêmeas nas quais não foram encontradas dilatações nem vestígio de saco ovariolar (nuliparas), observou-se que 32 delas estavam na fase III-V do desenvolvimento ovariolar de Christopher e Mer. E dentre as 54 uníparas observadas, 17 estavam na fase III-V de Christopher e Mer.

Observou-se maior freqüência de oogênese normal, sendo que a oogênese abortiva foi constatada em uma bípara e em duas uníparas (que não ovipuseram) conforme mostra a tabela 2 . 
Tabela 2: $N^{\circ}$ de oviposições realizadas por fêmeas de Oc. scapularis criadas em laboratório e o diagnóstico de idade fisiológica segundo a interpretação da Escola Nova e o desenvolvimento folicular segundo Christophers e Mer.

\begin{tabular}{|c|c|c|c|c|c|c|c|c|c|c|c|c|}
\hline \multirow{3}{*}{ Diagnóstico" } & \multicolumn{12}{|c|}{ Acompanhamento em laboratório } \\
\hline & \multicolumn{2}{|c|}{ Sem oviposição } & \multicolumn{2}{|c|}{1 oviposição } & \multicolumn{2}{|c|}{2 oviposições } & \multicolumn{2}{|c|}{3 oviposições } & \multicolumn{2}{|c|}{4 oviposições } & \multicolumn{2}{|c|}{5 oviposiçes } \\
\hline & $\mathrm{N}$ & $\%$ & $\mathrm{~N}$ & $\%$ & $\mathrm{~N}$ & $\%$ & $\mathrm{~N}$ & $\%$ & $\mathrm{~N}$ & $\%$ & $\mathrm{~N}$ & $\%$ \\
\hline Nulipara & 7 & 26,9 & 0 & 0,0 & 0 & 0,0 & 0 & 0,0 & 0 & 0,0 & 0 & 0,0 \\
\hline Nu FIII-V & 12 & 46,2 & 18 & 34,0 & 2 & 14,3 & 0 & 0,0 & 0 & 0,0 & 0 & 0,0 \\
\hline Unípara & 2 & 7,7 & 27 & 50,9 & 4 & 28,6 & 2 & 50,0 & 1 & 50,0 & 1 & 100,0 \\
\hline Uní FIII-V & 0 & 0,0 & 8 & 15,1 & 6 & 42,9 & 2 & 50,0 & 1 & 50,0 & 0 & 0,0 \\
\hline Bípara & 0 & 0,0 & 0 & 0,0 & 1 & 7,1 & 0 & 0,0 & 0 & 0,0 & 0 & 0,0 \\
\hline s/cond & 5 & 19,2 & 0 & 0,0 & 1 & 7,1 & 0 & 0,0 & 0 & 0,0 & 0 & 0,0 \\
\hline
\end{tabular}

* dissecção do ovário

$\mathrm{Na}$ figura $5 \mathrm{~A}$ pode-se observar o ovariolo com o óvulo na fase $\mathrm{V}$ do desenvolvimento de Christopher e Mer, pronto para ser fecundado. Ao redor deste óvulo há uma membrana transparente que, após a oviposição, se apresenta disforme e é chamada de saco ovariolar. A presença do saco ovariolar indica a ocorrência de oogênese normal (Figura 5B).

O saco ovariolar pode, no momento da dissecção, ser rompido e assim, apenas um vestígio de sua existência é observada, como mostra a Figura 5C.

A oogênese abortiva está ilustrada na Figura 6 onde, a fêmea apresentou duas dilatações no pedicelo ovariolar decorrentes de duas degenerações foliculares; assim, foi considerada bipara. 
A

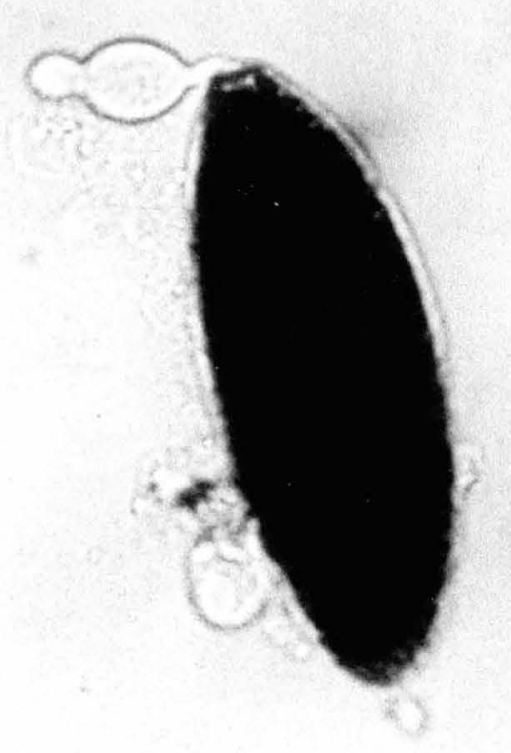

C
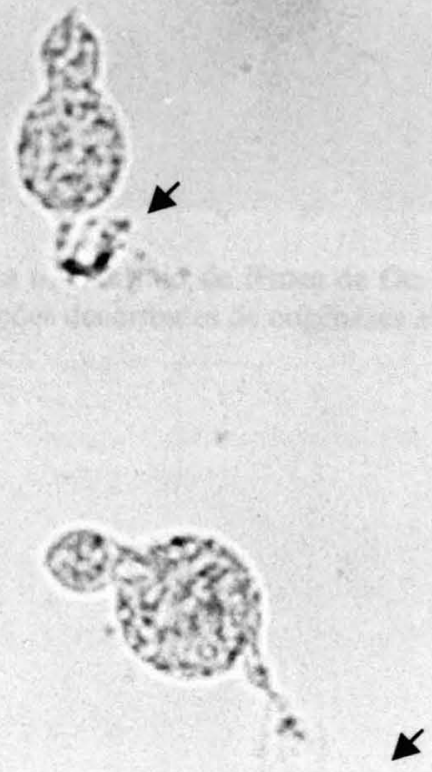

B

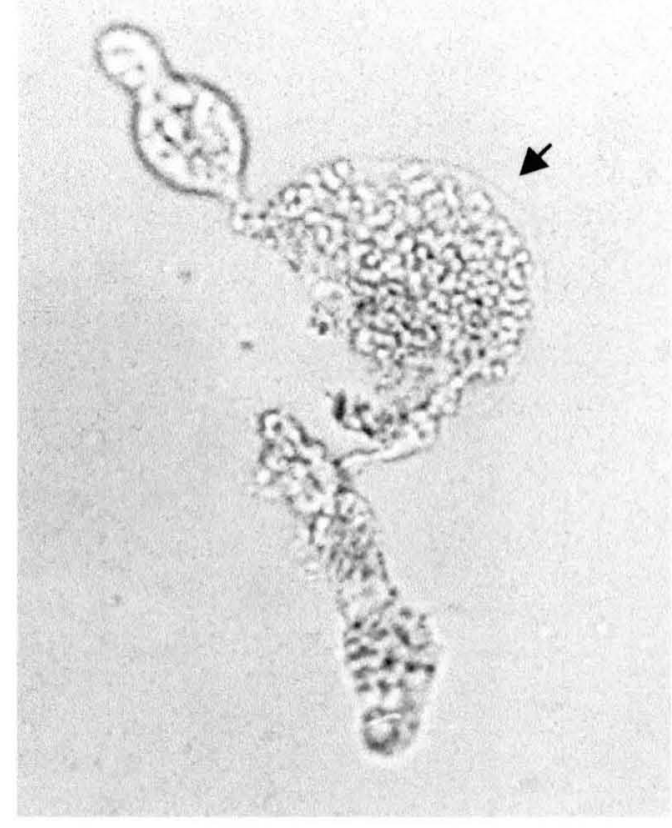

Figura 5. Morfologia de ovaríolos de fềmeas de Oc. scapularis dissecadas em laboratório (aumento de 400X).

(A) ovaríolo com óvulo fase $\mathrm{V}$ de Christpher e Mer dentro do saco ovariolar;

(B) saco ovariolar (após oviposição);

(C) mais acima - ovaríolo com vestígio de saco ovariolar; abaixo mostrando o saco ovariolar com membrana hialina. 


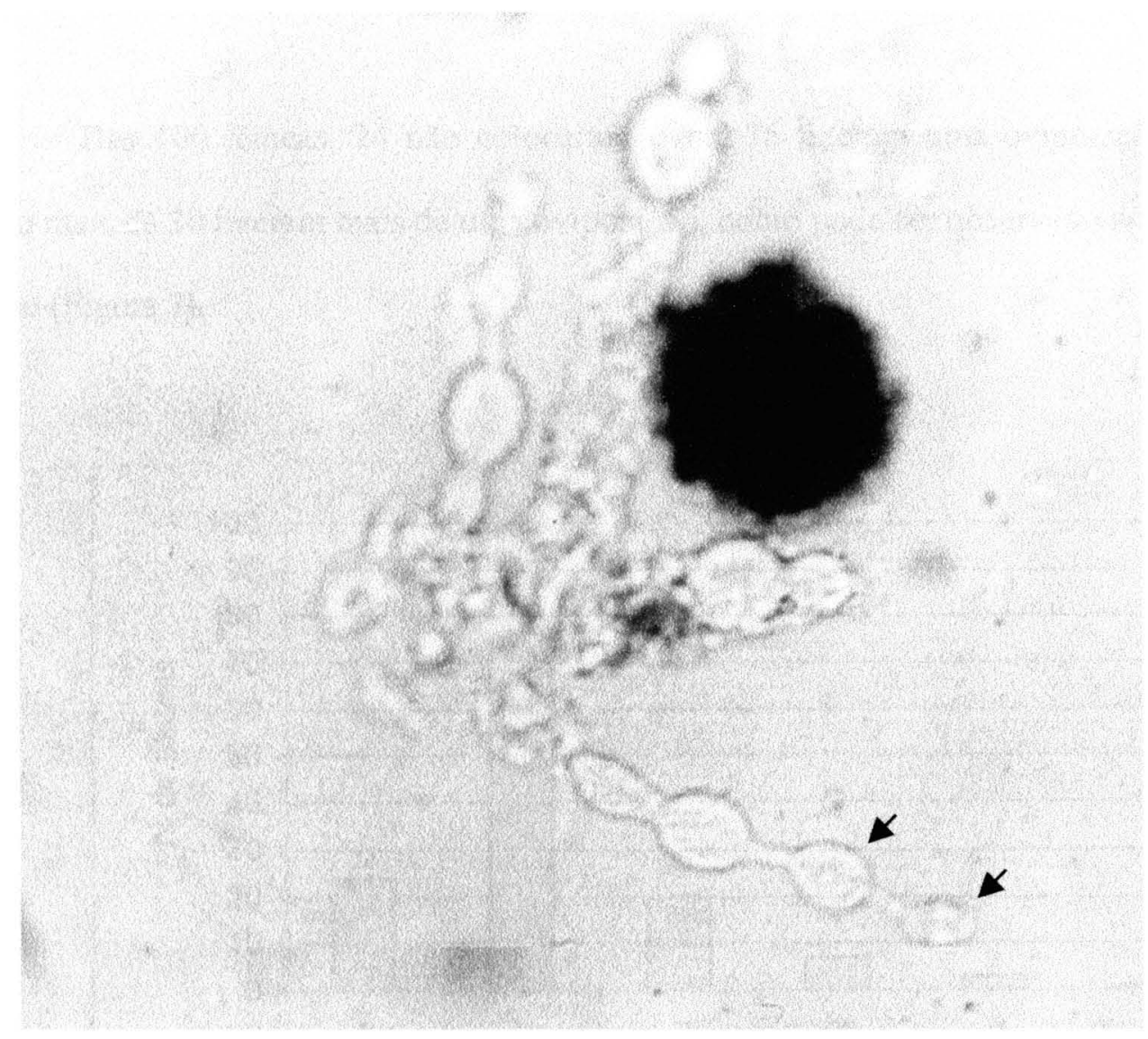

Figura 6. Ovaríolo de fêmea de Oc. scapularis considerada bípara apresentando duas dilatações decorrentes de oogêneses abortivas (aumento de 400X). 


\subsubsection{Freqüência de oviposição e média de ovos colocados.}

Das 100 fềmeas, 24 não colocaram ovos, 76 fizeram uma oviposição e um pouco mais de 20 fizeram mais de uma oviposição, como pode ser observado no gráfico abaixo (Figura 7).

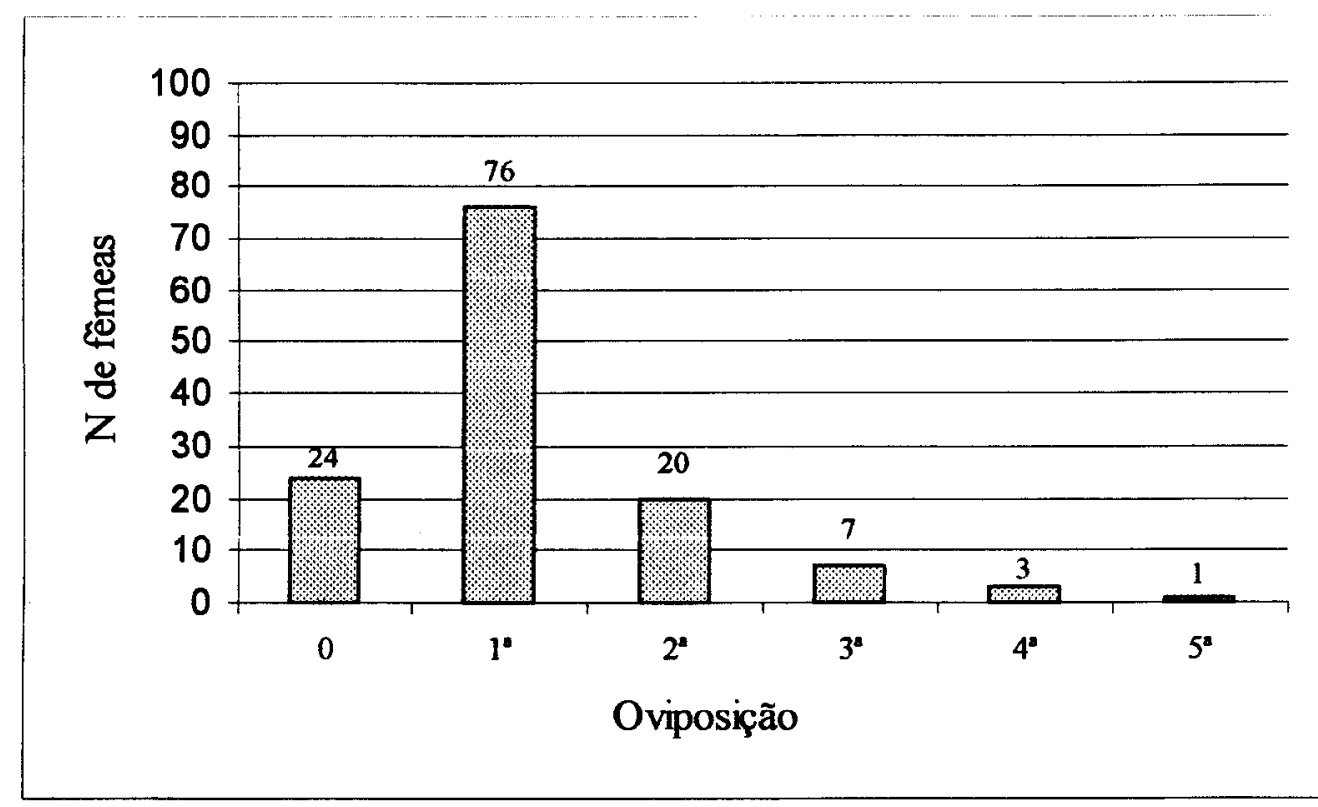

Figura 7: Número de fêmeas de Oc. scapularis criadas em laboratório que realizaram de 0 a 5 oviposições.

A figura 8 mostra a soma dos ovos colocados por todas as fêmeas de acordo com a oviposição. 


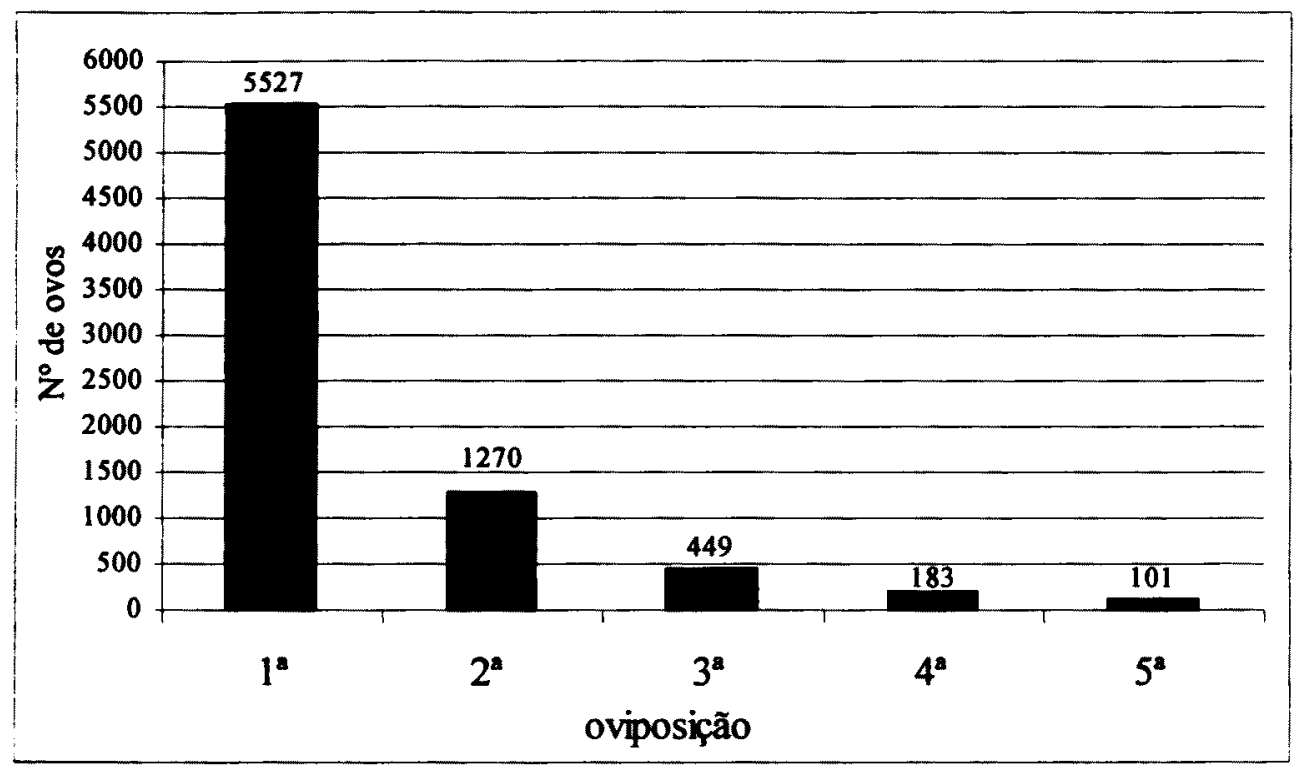

Figura 8: Número total de ovos de Oc. scapularis por oviposição em condiçães de laboratório.

Nota-se que o número de ovos decresce de uma oviposição para outra (figura 8) mas também o número de fềmeas paridas diminui (figura 7).

A média aritmética de ovos colocados (Figura 8) pelas fêmeas de $O c$. scapularis (Figura 7) na primeira oviposição foi de 73 ovos por fềmea, na $2^{a}$ oviposição a média de ovos foi de 64 ovos, 64 para a $3^{\text {a }}$ oviposição e 61 ovos para a $4^{\text {a }}$ oviposição. Uma fềmea chegou a colocar 101 ovos em sua $5^{a}$ oviposição. Os dados completos referentes ao número de ovos a cada oviposição de cada uma das 100 fêmeas estão na tabela 3 (Anexo 1).

A tabela 4 mostra a média de ovos colocados por repasto sangüíneo. Com um repasto sangüíneo, as fêmeas de Oc. scapularis conseguiram colocar mais de 59 ovos, chegando a ovipor até 101. A fềmea que necessitou realizar 4 repastos para uma 
oviposição, mostrou baixa produção colocando 3 ovos. A fêmea que se alimentou por 6 vezes produziu, em média, o mesmo número de ovos das que se alimentaram 3 vezes.

Tabela 4: Média de ovos por oviposição e quantidade de repastos sanguineos realizados pelas fềmeas de Oc.scapularis criadas em laboratório.

\begin{tabular}{lccccc}
\hline & $1^{\text {a }}$ ovip & $2^{\text {a }}$ ovip & $3^{\text {a }}$ ovip & $4^{\text {a }}$ ovip & $5^{\text {a }}$ ovip \\
\hline $1 \operatorname{Rep}$ & 82,6 & 64,7 & 83,5 & 59 & 101 \\
$2 \operatorname{Rep}$ & 76,6 & 57,8 & 38,3 & 62 & -- \\
$3 \operatorname{Rep}$ & 42,4 & 47,3 & -- & -- & -- \\
$4 \operatorname{Rep}$ & 3 & -- & -- & -- & -- \\
$5 \operatorname{Rep}$ & -- & -- & -- & -- & -- \\
$6 \operatorname{Rep}$ & 40 & -- & -- & -- & -- \\
\hline
\end{tabular}

\subsubsection{Verificação do diagnóstico da condição de paridade}

Entre as 26 fêmeas que não colocaram ovos, $19(73,07 \%)$ foram consideradas nuliparas, $2(7,69 \%)$ foram consideradas como uniparas e $5(19,23 \%)$ não puderam ser avaliadas.

Em relação às 53 fềmeas de $O c$. scapularis que ovipuseram uma vez, 18 $(33,96 \%)$ foram consideradas nuliparas na fase III-V do desenvolvimento ovariano segundo Christopher e Mer, 27 (50,94\%) foram avaliadas como uniparas e 8 (15,09\%) como uníparas na fase III-V de Christopher e Mer.

Foi diagnosticada como bipara, apenas uma fềmea $(7,14 \%)$ de 14 que haviam colocado dois lotes de ovos. Sendo que a maior parte delas $(42,86 \%)$ foi diagnosticada como unipara na fase III-V do desenvolvimento ovariano. 
Pode-se observar também, que entre as 7 fêmeas que realizaram mais de 3 oviposiçð̃es, o diagnóstico foi de uniparidade para 4 delas e uniparidade na fase III-V do desenvolvimento ovariano para 3 delas.

Dos casos considerados como "sem condiçð̃es" de diagnóstico, 5 não haviam colocado ovos, e uma havia feito duas oviposições.

Estes dados são observados na tabela 2 onde, na primeira coluna à esquerda, encontra-se o estado de paridade observado. Esta informação foi cruzada com as anotaç̃̃es feitas em laboratório. Assim, pudemos comparar os resultados obtidos por meio da técnica de dissecção com os resultados já anotados.

\subsubsection{Relação entre repasto sangüíneo e ciclo gonotrófico}

Entre as 100 fềmeas de $O c$. scapularis criadas em laboratório, 74 fizeram pelo menos uma oviposição. Destas, $35(47,3 \%)$ realizaram apenas um repasto sangüineo para ovipor, e $39(52,7 \%)$ necessitaram realizar mais de um repasto para conseguir ovipor.

Das 21 fềmeas que ovipuseram pela segunda vez, $15(71,4 \%)$ necessitaram de mais de um repasto. Entre as que colocaram 3 lotes de ovos $57,1 \%$ fizeram um único repasto para cada ciclo gonotrófico e $42,9 \%$ chegaram a fazer um segundo repasto sangüíneo.

A percentagem de fềmeas que ovipuseram 4 vezes e realizaram um repasto de sangue para cada ciclo foi de $33,3 \%$ e $66,7 \%$ precisaram buscar a fonte sangüinea pela segunda vez. 
Uma fềmea chegou a realizar 5 oviposições, necessitando de um repasto para realizar a quinta postura. Observou-se também uma fêmea que se alimentou 6 vezes antes da primeira oviposição.

A tabela 5 mostra o número e percentagem de repastos feitos pelas fềmeas para a realização da primeira à quinta oviposição. A tabela foi reagrupada abaixo para melhor visualização da necessidade de mais de um repasto sangüineo para a oviposição.

Tabela 5: Quantidade de repastos realizados por fềmeas de Ochlerotatus scapularis criadas em laboratório para ovipor.

\begin{tabular}{|c|c|c|c|c|c|c|c|c|c|c|}
\hline & \multicolumn{2}{|c|}{$\mathrm{l}^{\mathrm{a}} \mathrm{o}$} & \multicolumn{2}{|c|}{$2^{\mathrm{a}} \mathrm{o}$} & \multicolumn{2}{|c|}{$3^{a} 0$} & \multicolumn{2}{|c|}{$4^{3} 0$} & \multicolumn{2}{|c|}{$5^{a} 0$} \\
\hline & $\mathrm{N}$ & $\%$ & $\mathrm{~N}$ & $\%$ & $\mathrm{~N}$ & $\%$ & $\mathrm{~N}$ & $\%$ & $\mathrm{~N}$ & $\%$ \\
\hline $1 \mathrm{Rep}$. & 35 & 47,3 & 6 & 28,6 & 4 & 57,1 & 1 & 33,3 & 1 & 100,0 \\
\hline 2 Rep. & 30 & 40,5 & 11 & 52,4 & 3 & 42,9 & 2 & 66,7 & 0 & 0,0 \\
\hline 3 Rep. & 7 & 9,5 & 4 & 19,0 & 0 & 0,0 & 0 & 0,0 & 0 & 0,0 \\
\hline 4 Rep. & 1 & 1,4 & 0 & 0,0 & 0 & 0,0 & 0 & 0,0 & 0 & 0,0 \\
\hline 5 Rep. & 0 & 0,0 & 0 & 0,0 & 0 & 0,0 & 0 & 0,0 & 0 & 0,0 \\
\hline 6 Rep. & 1 & 1,4 & 0 & 0,0 & 0 & 0,0 & 0 & 0,0 & 0 & 0,0 \\
\hline \multirow[t]{3}{*}{ Totalde fêmeas } & 74 & 100 & 21 & 100 & 7 & 100 & 3 & 100 & 1 & 100 \\
\hline & \multicolumn{2}{|c|}{$1^{\mathrm{a}} \mathrm{o}$} & \multicolumn{2}{|c|}{$2^{\mathrm{a}} \mathrm{o}$} & \multicolumn{2}{|c|}{$3^{a} 0$} & \multicolumn{2}{|c|}{$4^{a} 0$} & \multicolumn{2}{|c|}{$5^{\mathrm{a}} \mathrm{o}$} \\
\hline & $\mathrm{N}$ & $\%$ & $\mathrm{~N}$ & $\%$ & $\mathrm{~N}$ & $\%$ & $\mathrm{~N}$ & $\%$ & $\mathrm{~N}$ & $\%$ \\
\hline $1 \mathrm{Rep}$ & 35 & 47,3 & 6 & 28,6 & 4 & 57,1 & 1 & 33,3 & 1 & 100,0 \\
\hline mais de 1 Rep & 39 & 52,7 & 15 & 71,4 & 3 & 42,9 & 2 & 66,7 & 0 & 0,0 \\
\hline Total de fêmeas & 74 & 100 & 21 & 100 & 7 & 100 & 3 & 100 & 1 & 100 \\
\hline
\end{tabular}

Foi observado que duas fềmeas chegaram a realizar 8 repastos sangüineos, conforme mostra tabela 6 . 


\subsubsection{Intervalo entre repastos}

Na mesma tabela (tabela 6) é observado o intervalo em dias entre um repasto sangüineo e outro de fềmeas de $O c$.scapularis criadas em laboratório. Pode-se apontar que a maior parte dos intervalos entre um repasto e outro, em mais de $50 \%$ das fêmeas, foi de 2 dias. Apenas duas fềmeas $(3,4 \%)$ demoraram 6 dias entre o primeiro repasto e o segundo.

Tabela 6: Intervalo em dias entre um repasto e outro de fềmeas de $O c$. scapularis criadas em laboratório.

\begin{tabular}{cccccccccccccccc}
\hline & \multicolumn{1}{c}{$1^{\circ}$ Int } & \multicolumn{2}{c}{$2^{\circ}$ Int } & \multicolumn{3}{c}{$3^{\circ}$ Int } & \multicolumn{3}{c}{$4^{\circ}$ Int } & \multicolumn{3}{c}{$5^{\circ}$ Int } & \multicolumn{2}{c}{$6^{\circ}$ Int } & \multicolumn{2}{c}{$7^{\circ}$ Int } \\
\hline & $\mathrm{N}$ & $\%$ & $\mathrm{~N}$ & $\%$ & $\mathrm{~N}$ & $\%$ & $\mathrm{~N}$ & $\%$ & $\mathrm{~N}$ & $\%$ & $\mathrm{~N}$ & $\%$ & $\mathrm{~N}$ & $\%$ \\
1 dia & 0 & 0,0 & 3 & 9,4 & 1 & 5,0 & 0 & 0,0 & 1 & 16,7 & 0 & 0,0 & 0 & 0,0 \\
2 dias & 41 & 70,7 & 19 & 59,4 & 12 & 60,0 & 5 & 50,0 & 3 & 50,0 & 2 & 100,0 & 1 & 50,0 \\
3 dias & 6 & 10,3 & 4 & 12,5 & 4 & 20,0 & 2 & 20,0 & 2 & 33,3 & 0 & 0,0 & 1 & 50,0 \\
4 dias & 7 & 121 & 5 & 15,6 & 3 & 15,0 & 1 & 10,0 & 0 & 0,0 & 0 & 0,0 & 0 & 0,0 \\
5 dias & 2 & 3,4 & 1 & 3,1 & 0 & 0,0 & 1 & 10,0 & 0 & 0,0 & 0 & 0,0 & 0 & 0,0 \\
6 dias & 2 & 3,4 & 0 & 0,0 & 0 & 0,0 & 1 & 10,0 & 0 & 0,0 & 0 & 0,0 & 0 & 0,0 \\
\hline Total & 58 & 100 & 32 & 100 & 20 & 100 & 10 & 100 & 6 & 100 & 2 & 100 & 2 & 100 \\
\hline
\end{tabular}

$1^{\circ}$ Intervalo= periodo em dias entre o $1^{\circ}$ e o $2^{\circ}$ repasto. $2^{\circ}$ Intervalo $=$ periodo em dias entre o $2^{\circ}$ e o $3^{\circ}$ repasto $3^{\circ}$ Intervalo $=$ periodo entre o $3^{\circ}$ e o $4^{\circ}$ repasto $4^{\circ}$ intervalo $=$ periodo entre o $4^{\circ}$ e $5^{\circ}$ repasto
$5^{\mathrm{J}}$ Intervalo = periodo ente o $5^{\mathrm{N}}$ e $6^{\mathrm{u}}$ repasto

$6^{\circ}$ Intervalo $=$ periodo entre $\circ 6^{\circ}$ e $7^{\circ}$ repasto

$7^{\circ}$ Intervalo $=$ periodo entre o $7^{\circ}$ e $8^{\circ}$ repasto

\subsubsection{Sobrevivência de fêmeas de Ochlerotatus scapularis}

Sob condiçð̃es laboratoriais, pudemos observar a sobrevivência de $O c$. scapularis até 26 dias. A figura 9 coloca através de um gráfico em barras, a quantidade de fềmeas e o respectivo número de dias de sobrevida. 


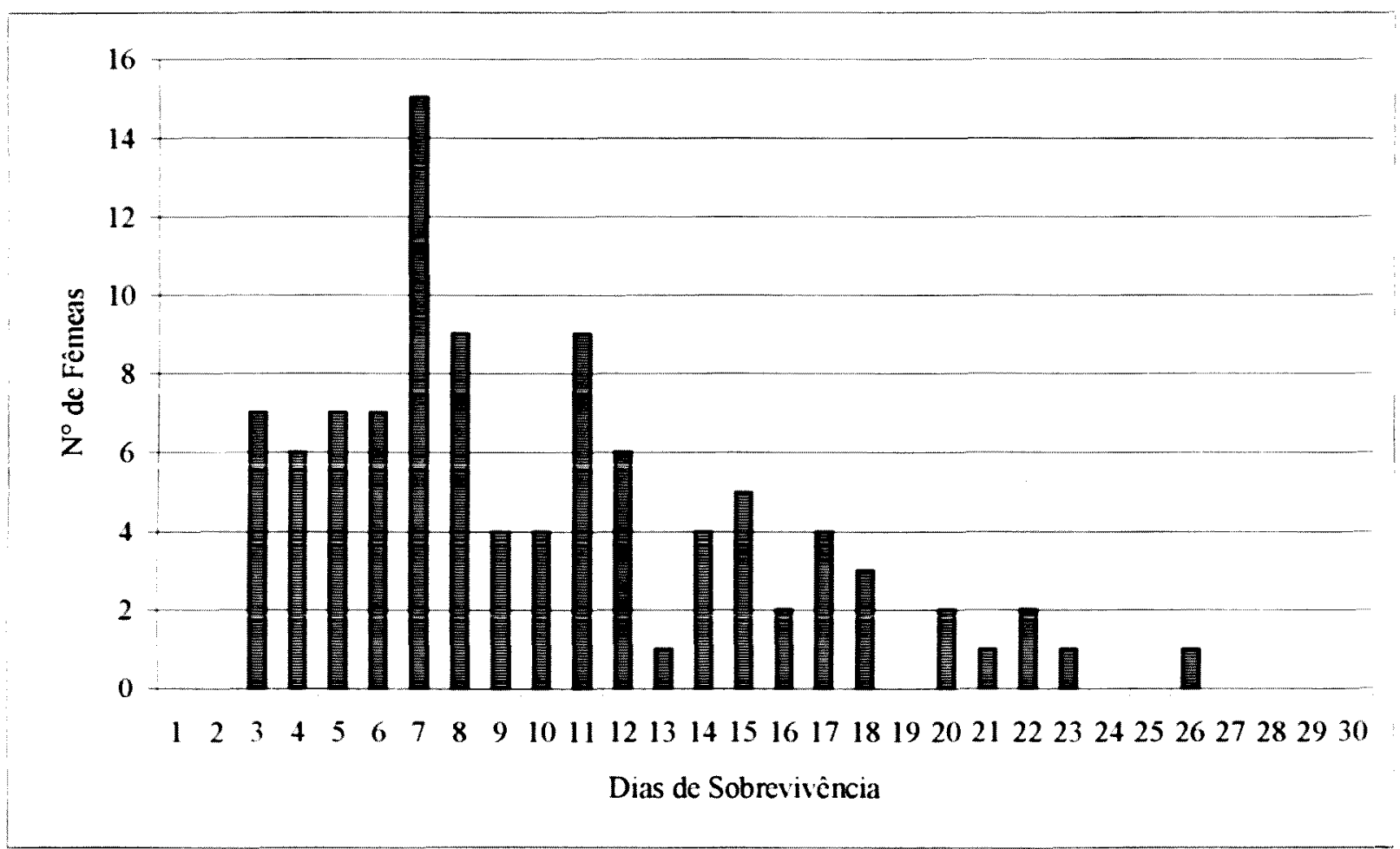

Figura 9: Sobrevivència de $O$ c. scapularis em condiç̣̃es de laboratónio.

O comprimento do ciclo gonotrofico foı de 4 dias para $37,7 \%$ das fềmeas e 3 dias para $23,6 \%$. Uma pequena parte $(2,7 \%)$ necessitou de mals de 10 dias para que o ciclo se completasse, chegando até o $15^{\circ}$ dia. A duraçào do ciclo gonotrófico observado em laboratório pode ser observado na figura 10 


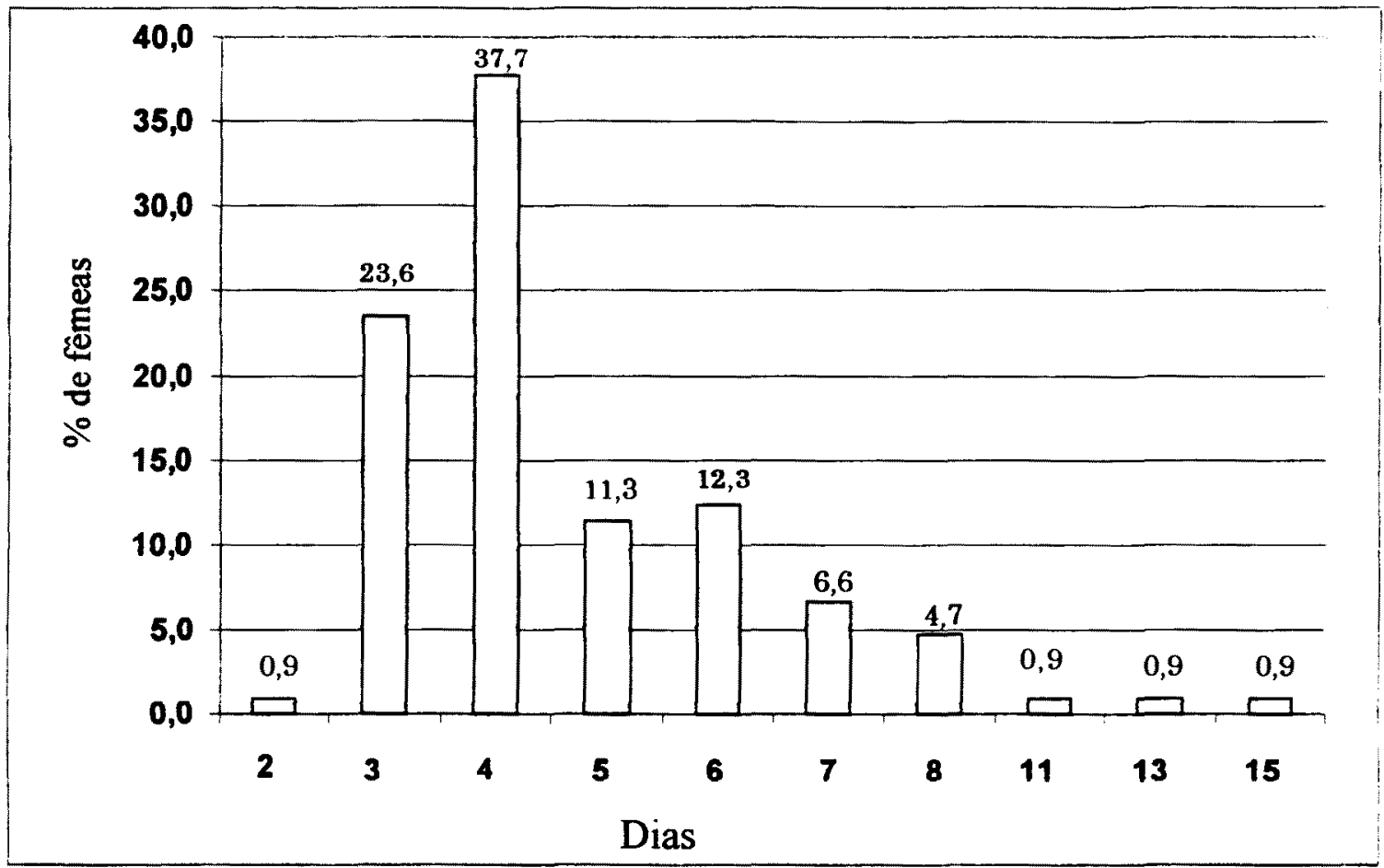

Figura 10.: Duração do ciclo gonotrófico de fêmeas de Ochlerotatus scapularis em condições de laboratório.

\subsection{Campo}

Foram dissecadas 1180 fêmeas de Oc. scapularis ao longo do ano. Em todos os meses foram encontradas fềmeas nuliparas e paridas. Quanto à ocorrência de oogêneses abortivas, estas também foram observadas na maior parte das coletas com exceção dos meses de abril e fevereiro (tabela 7). 
Tabela 7: Número de Oc. scapularis dissecados para a avaliação de estado de paridade, capturados com a técnica de aspiração manual. Abril de 2003 a março de 2004. Vale do Ribeira, SP.

\begin{tabular}{lrrrrrrrrrrrrrr}
\hline & abr & mai & jun & jul & ago & set & out & nov & dez & jan & fev & mar & total & $\%$ \\
\hline Nulípara & 46 & 35 & 38 & 68 & 35 & 29 & 21 & 26 & 25 & 10 & 22 & 45 & 400 & 33,9 \\
Nulíp. Fase III-V & 8 & 1 & 1 & 2 & 0 & 1 & 1 & 1 & 1 & 2 & 0 & 0 & 18 & 1,5 \\
Unipara & 30 & 36 & 24 & 53 & 51 & 74 & 62 & 48 & 18 & 40 & 52 & 95 & 583 & 49,4 \\
Unip. Fase III-V & 6 & 9 & 4 & 3 & 6 & 11 & 3 & 6 & 2 & 5 & 4 & 13 & 72 & 6,1 \\
Bipara & 0 & 2 & 3 & 6 & 5 & 7 & 2 & 7 & 1 & 7 & 0 & 6 & 46 & 3,9 \\
Sem Condiç̃es & 16 & 3 & 10 & 6 & 7 & 3 & 2 & 5 & 1 & 2 & 4 & 2 & 61 & 5,2 \\
\hline Total & 106 & 86 & 80 & 138 & 104 & 125 & 91 & 93 & 48 & 66 & 82 & 161 & 1180 & 100 \\
\hline
\end{tabular}

Das 1180 fềmeas dissecadas, 655 (55,5\%) foram consideradas uníparas e 418 $(35,4 \%)$ como nuliparas e $46(3,9 \%)$ foram avaliadas como biparas. Do total de dissecções realizadas, $61(5,2 \%)$ não puderam ser avaliadas.

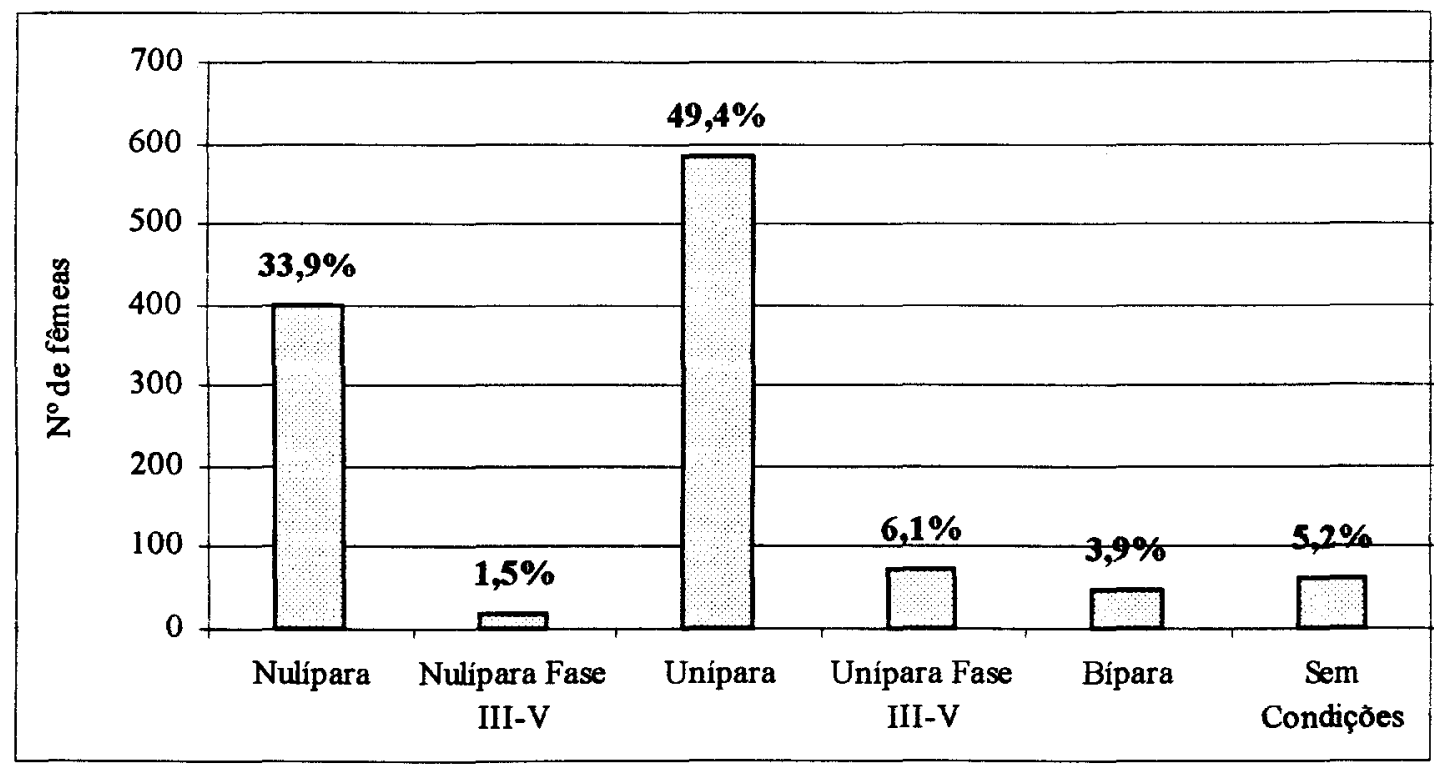

Figura 11: Número e percentagem de Oc. scapularis dissecados e a avaliação de estado de paridade, capturados com a técnica da aspiração manual de abril de 2003 a março de 2004. Vale do Ribeira, SP. 


\section{DISCUSSÃO}

O estudo da idade fisiológica está ligado à capacidade vetora, que depende de vários fatores como a densidade do inseto, antropofilia, freqüência de picadas ao homem, sobrevivência e a competência (FORATTINI 1962; 1992).

Com os dados obtidos em laboratório, observando-se fêmeas com idade cronológica conhecida, verificando o seu comportamento durante toda a vida, pudemos acompanhar o desenvolvimento do ciclo gonotrófico, a ocorrência da oogênese normal ou abortiva e relacioná-las com os repastos sanguineos.

Inicialmente, foi pensado em se trabalhar com fềmeas copuladas em laboratório utilizando-se, para isto, a técnica da cópula induzida (CONSOLI e LOURENÇO-DEOLIVEIRA 1994). A técnica chegou a ser aplicada num piloto do trabalho em laboratório, porém, devido às dificuldades encontradas na metodologia, o pouco sucesso na obtenção de ovos fecundados e a constatação de que as fềmeas tinham sua sobrevida diminuída, chegamos à conclusão de que seria mais interessante para o trabalho a utilização de fềmeas de $O c$. scapularis (de primeira geração) não fecundadas, uma vez que observamos que a inseminação não pareceu ser pré-requisito para a produção de ovos. KAKITANI (1997) observou o mesmo em Anopheles albitarsis em condições laboratoriais.

A manipulação dos insetos durante a cópula induzida poderia causar estresse, interferindo na sua sobrevida. Considerando que o objetivo do estudo não tinha relação com a fecundidade do ovo e sim com a atividade hematófaga, comprimento do ciclo 
gonotrófico e sobrevivência, assim, optou-se por mudar a metodologia. Possivelmente resultados diferentes poderiam ter sido observados, o que chama a atenção para novos estudos comparativos entre fềmeas copuladas e não copuladas, por exemplo. FORATTINI (2002) levanta a hipótese da cópula ser um fator estimulante para a hematofagia e desenvolvimento dos ovos o que é denominado estímulo espermatogênico. Para algumas espécies a inseminação é pré-requisito para o desenvolvimento dos ovos como é o caso do An. subpictus (ROY 1940 apud KAKITANI 1992).

Ficou constatado que seis fêmeas criadas em laboratório e 61 capturadas no campo, não puderam ser avaliadas por condições ruins de observação de seus ovários. Estas condições se caracterizaram pela impossibilidade de analisar os ovaríolos, que se apresentavam em estado de degeneração. $O$ aspecto era de um conteúdo celular escuro, sem distinção das estruturas. Não encontramos explicação para essa condição, já que as fềmeas criadas no laboratório eram dissecadas diariamente logo após a morte. E as fềmeas coletadas no campo, foram anestesiadas rapidamente com éter e, mesmo assim, a situação se repetiu.

\subsection{Freqüência de oogênese normal e abortiva}

$O$ estudo da oogênese contribui para determinar o estado de paridade. $O$ diagnóstico ovariolar se dá por meio da observação de dilatações encontradas no ovariolo e do saco terminal (FOX e BRUST 1994). 
LEA et al. (1978) colocam que uma grande proporção de ovariolos completa oogênese normal ao se alimentar totalmente.

Com a manutenção de fềmeas de Oc. scapularis em laboratório, tivemos a oportunidade de acompanhar todo o desenvolvimento de 100 fềmeas, dentre as quais observamos que $74 \%$ chegaram a ovipor pelo menos uma vez (tabela 2 ). Ao dissecarmos estas fêmeas, pudemos observar, baseados nos preceitos da Escola Nova, que apenas $55 \%$ delas haviam sido diagnosticadas como tendo parido (entre elas as uniparas e a bípara). Os dados se explicam quando observamos que das 100 fềmeas, 32 se apresentavam no estágio III-V do desenvolvimento ovariano. Nesta fase, os ovariolos se apresentaram de tal forma que a identificação de dilatação ou saco ovariolar ficou dificultada ou impedida. Portanto, entre essas fềmeas que se apresentavam na fase III-V havia nuliparas e uniparas, mas, na ausência de vestigios de oviposição, optou-se por diagnosticá-las como nulíparas.

Das fềmeas coletadas e dissecadas observou-se que $59,4 \%$ delas eram oniparas. $O$ fato das fềmeas terem sido aspiradas permite inferir que elas tenham se aproximado do coletor para realizar o segundo repasto. Este dado tambem foi verificado por KAKITANI et al. (2003) em Anopheles marajoara que mencionam a importância deste dado associado à longevidade, parâmetro importante na estimativa da capacidade do vetor.

No campo, observou-se que $55,5 \%$ das 1180 fêmeas dissecadas, foram uníparas representando percentagem maior em relação às nulíparas $(35,4 \%)$. Em relação aos resultados de dissecçßes ao longo do ano, nota-se que em todos os meses foram encontradas fêmeas nuliparas e paridas. Quanto à ocorrência de oogêneses abortivas, 
estas também foram observadas na maior parte das coletas com exceção dos meses de abril e fevereiro (tabela 7).

Foram observadas, em laboratório, oogêneses abortivas em três fêmeas, sendo que uma foi bípara, onde se notou uma dilatação e vestígio de saco ovariolar, e nas demais somente a dilatação foi encontrada. SOKOLOVA (1994) diz que oogêneses abortivas podem ser explicadas por vários fatores, dentre eles a abstinência de alimentação sangüinea. Neste experimento, as duas fêmeas uníparas, numeradas como 46 e 51 na tabela 1 (anexo 1) fizeram um e dois repastos sangüineos consecutivamente, sendo que a primeira chegou a ficar 6 dias sem se alimentar, e a segunda ficou 5 dias. No entanto, outras fêmeas como as de número $24,29,43,75$ e 100 da mesma tabela, chegaram a demorar iguais 5 a 6 dias para voltar a se ingurgitar e não apresentaram oogêneses abortivas, pelo contrário, todas ovipuseram ao menos duas vezes.

Ainda segundo SOKOLOVA (1994), a degeneração folicular se caracteriza de granulações no epitélio folicular, sendo que, ao final do processo de degeneração, formase a dilatação e, gradualmente, esses grânulos vão desaparecendo.

\subsection{Número de oviposiçōes e média de ovos colocados}

Observando a quantidade de repastos realizados para cada oviposição, notamos que a necessidade de se alimentar várias vezes com sangue para ovipor, não significa que a fềmea produzirá número maior de ovos; pelo contrário, a produção média de ovos foi maior com um repasto sangüíneo para cada oviposição. Parece haver relação entre quantidade de sangue ingerido ou a qualidade de nutrientes para o desenvolvimento dos 
ovos. Sobre o número de ovos, a presença de açúcar na alimentação das fêmeas pode, segundo FOSTER (1995), influenciar sua fecundidade.

De acordo com HIEN (1976), a quantidade dos ovos colocados está associada a condições como: idade físiológica, peso após emergência da fềmea e também do volume ingerido de sangue.

\subsection{Diagnóstico e condição de paridade}

Com os dados de oviposição obtidos em laboratório, verificamos que $55 \%$ dos casos, quando comparados ao diagnóstico de paridade por meio da dissecção dos ovários, foram concordantes. Isto porque 19 fêmeas que não ovipuseram foram consideradas nuliparas, 35 que haviam colocado ovos uma vez foram diagnosticadas uniparas e uma fềmea que ovipôs duas vezes foi considerada bípara (tabela 2).

Os dados foram subestimados em $37 \%$, pois de 53 fềmeas que haviam feito uma oviposição, 18 foram consideradas como nuliparas e de 21 que fizeram mais de uma oviposição, 19 foram diagnosticadas como uniparas. Para a primeira situação, a explicação reside no fato destas fêmeas se encontrarem na fase III-V de Christopher e Mer, o que dificulta a visualização de saco ovariolar. Para o segundo caso, os dados podem ser explicados pela interpretação da Escola Nova, que diz que, quando há subseqũentes oviposiçð̃es, só o vestigio da última será encontrado e a fềmea será dita unípara.

Por último, encontramos $2 \%$ de casos superestimados, onde as duas fềmeas encontradas tinham uma dilatação no pedicelo ovariolar indicando oogênese abortiva. 
Assim, estas fềmeas não chegaram a ovipor, mas realizaram o repasto. NAYAR e KNIGHT (1981) realizaram um estudo sobre a ocorrência de dilataçð̃es em fêmeas nuliparas de Culex nigripalpus, às quais foi oferecida apenas alimentação açucarada. Os autores observaram que de 16 a 50\% das fêmeas apresentavam uma dilatação com uma semana após a emergência e, durante as próximas duas semanas, a maior parte delas tinha de 1 a 3 dilatações. Num trabalho anterior, NAYAR e KNIGHT (1981b) verificaram autogenia para os Culex nigripalpus, quando fềmeas desta espécie desenvolveram ovos autógenos depois de 4 a 7 dias da emergência. Assim, os autores sugerem uma possivel associação entre o aparecimento de dilatações em nuliparas e o desenvolvimento de ovos autógenos.

MENEZES (2002), observou uma possivel autogenia para Oc. scapularis quando constatou a presença de fêmeas da espécie na fase IV de Christopher e Mer, sem indício de que haviam se alimentado anteriormente de sangue, porém, ainda neste trabalho, a autora coloca que a grande maioria das fềmeas apresentava indício de terem se alimentado para o desenvolvimento ovariano indicando a anautogenia. No presente trabalho, não foi constatado o desenvolvimento ovariano além da fase I e II de Christopher e Mer, sem prévia alimentação sangüinea, sugerindo a anautogenia.

Apesar de ser um número representativo de dados subestimados, a eficácia do método não foi diminuida, já que a nós importava estimar a procura e conclusão do repasto e não efetivamente a oviposição. Portanto, encontrando dilataçð̃es e estágios avançados na oogênese, poderia haver indicação de que a fềmea se alimentou anteriormente e teve o contato com o hospedeiro. 
Da mesma forma, os dados superestimados não surpreenderam por se tratar de fềmeas que haviam tido oogêneses abortivas, isto é, não chegaram a ovipor, porém se alimentaram.

\subsection{Relação entre repasto sangüíneo e ciclo gonotrófico}

Um número expressivo de fêmeas observadas em laboratório realizou mais de um repasto para completar o ciclo gonotrófico. De 106 ciclos completados, cerca de $55 \%$ das fêmeas se alimentaram mais de uma vez antes de ovipor, chegando a fazer até 6 repastos sangüineos. O contrário não foi observado, ou seja, a ocorrência de mais de uma oviposição para um repasto sangüineo.

O intervalo de tempo curto entre a realização dos repastos sangüineos aumenta a oportunidade de contato com o hospedeiro, e este é um parâmetro importante discutido na capacidade vetora da espécie.

Observamos na tabela 6 que em todos os repastos realizados, mais de $50 \%$ das fềmeas voltaram a se alimentar em 2 dias, e que o comprimento do ciclo gonotrófico (Figura 9) foi de 4 dias para a maior parte das fềmeas $(37,7 \%)$ indicando assim uma possivel discordância gonotrófica.

MENEZES (2002) levantou a hipótese de discordância gonotrófica para Oc. scapularis quando encontrou estágios avançados de oogênese em fềmeas desta espécie repletas de sangue. 
A constatação deste comportamento indica que pode haver maior oportunidade de contato do mosquito com hospedeiros diferentes e, conseqüentemente, maiores serão as chances da fềmea se infectar e transmitir o agente infeccioso.

KLOWDEN (1981) (apud KLOWDEN e BRIEGEL 1994) observou que privar a fềmea de Aedes aegypti de carboidrato aumenta significativamente sua procura pelo hospedeiro durante a oogênese, sugerindo assim que uma deficiência na alimentação pode levar a fềmea de culicídeo a fazer mais de um repasto para ovipor.

Com os dados obtidos das atividades no campo, observamos que 90 fềmeas $(7,6 \%)$ do total dissecado estavam na fase III-V do desenvolvimento ovariano de Christopher e Mer, o que indica que estavam em busca de mais um repasto sangüineo para a oviposição, reforçando a hipótese de discordância gonotrófica.

\subsection{Sobrevivência}

A sobrevivência de Oc. scapularis chegou a 26 dias sob condições laboratoriais.

Conhecer a duração do ciclo gonotrófico é uma das maneiras de estimar a sobrevivência do mosquito. No laboratório, cerca de $62 \%$ das fêmeas completaram o ciclo em até 4 dias e quase $38 \%$ precisaram de 5 até 15 dias para realizar a oviposição após o repasto. SANTOS (2001) observou em laboratório a duração do ciclo gonotrófico de Anopheles (Kerteszia) para os quais só um repasto sangüineo foi oferecido. A autora verificou que a duração média foi de 3,5 dias e, quando vários repastos foram 
oferecidos, houve um acréscimo na duração do ciclo para 4,84 dias devido, provavelmente, à diminuição da mortalidade.

CHADEE (1999) observou, em laboratório, o comprimento do ciclo gonotrófico, em Anopheles bellator. Seus dados indicaram que a segunda oviposição levou mais horas para acontecer do que a primeira. Para o primeiro ciclo gonotrófico, a espécie somente ovipôs após 57 horas do repasto sangüíneo e após 61 horas para o segundo ciclo gonotrófico.

No presente trabalho, foram contabilizadas até 5 oviposições, considerando que a média observada para a conclusão de cada ciclo foi de 4 dias, a estimativa da idade seria de 20 dias aproximando-se da idade real observada.

Num trabalho experimental, MICHELL e FORATTINI (1984), observaram que o periodo de incubação extrínseca para o vírus da Encefalite Rocio em $O c$. scapularis é de 20 a 21 dias, assim a sobrevida observada nesta população seria suficiente para o desenvolvimento do agente etiológico.

FERNÁNDEZ e FORATTINI (2003) observaram que as fêmeas de Aedes albopictus alimentadas com solução açucarada, quando comparadas com as alimentadas somente com sangue, mostraram maior esperança de vida ao nascer, isso porque o sangue humano não forneceria os aminoácidos necessários para a subsistência.

A longevidade é fator importante para determinar a capacidade vetora de culicídeos, no entanto concordo com KAKITANI (1997) quando a autora coloca que este aspecto não deve ser analisado isoladamente e sim somado a densidade e antropofilia. 


\section{CONCLUSÕES}

Diante dos resultados obtidos com o material de campo e o de laboratório, observamos que:

- A ocorrência da oogênese abortiva foi bastante reduzida tanto no material de campo como no de laboratório, indicando o sucesso de oviposição daquela população.

- Com os dados obtidos em laboratório, observou-se que o diagnóstico do grau de paridade, segundo os conceitos da Escola Nova, foi, na maior parte das vezes subestimado, indicando que o método não é eficiente para medir o número de oviposiçðes realizadas pelas fềmeas sendo assim, poderia haver um número maior de fềmeas multiparas na população.

- A duração do ciclo gonotrófico em condições de laboratório foi de 4 dias, aproximadamente, e o intervalo entre os repastos sangüineos de 2 dias. Isto sugere a necessidade de, pelo menos, dois repastos sangüineos para cada ciclo gonotrófico, caracterizando a existência de discordância gonotrófica.

- Em condições de laboratório, foi possivel verificar uma sobrevida de até 26 dias, tempo suficiente para o desenvolvimento do virus da Encefalite Rocio, que é de 20 a 21 dias (incubação extrinseca). 


\section{CONSIDERACÕES FINAIS}

Ao estudar fêmeas de idade conhecida e compararmos com o diagnóstico seguindo os preceitos da Escola Nova, pudemos observar a veracidade dos fundamentos desta Escola, pois nos ovariolos de fêmeas com oviposiçð̃es bem-sucedidas havia sempre o saco ovariolar ou vestígio do mesmo. Para a Escola Clássica, a cada oviposição uma dilatação seria formada no pedicelo ovariolar, o que não ocorreu em nossas observações. Houve uma fêmea que ovipôs por cinco vezes e nenhuma dilatação foi encontrada em seu pedicelo.

Pudemos observar uma provável anautogenia para a espécie, já que não foram encontrados ovariolos em fase de desenvolvimento avançado de Christopher e Mer, sem alimentação prévia com sangue.

Devido à capacidade operacional, apenas parte do material é dissecado, considerando a alta densidade da espécie em periodos pós-chuvas, a amostra pode não ser tão representativa, não servindo para análises estatísticas em relação à sazonalidade.

É importante colocar que em laboratório, era oferecido às fêmeas, alimento sangüineo em abundância, ou seja, estas não necessitaram sair em busca do hospedeiro sofrendo as intempéries. Assim, na maior parte das vezes as fềmeas se ingurgitaram completamente. Por outro lado o confinamento parecia causar estresse aos insetos, principalmente quando dentro de Borrel. Os mosquitos que estavam nas gaiolas sobreviviam por mais dias (até 60 dias aproximadamente), mesmo sem a oferta de repastos sangüineos. 
Tais observações indicam que o método não é um bom indicador para o estudo da produção de ovos de culicideos, já que os dados se apresentaram subestimados, na sua maioria.

O estudo da paridade pode ser importante para a estimativa do contato vetor/hospedeiro. Os dados obtidos com a técnica da dissecção e interpretados pela Escola Nova são confiáveis, porém, ainda pensando nos casos subestimados, informações importantes, como o tempo de sobrevida, poderiam também ser subestimados. A eficácia do método pode ser plena quando associada a outros estudos. 


\section{REFERÊNCIAS}

1. Ahid, SMM, Lourenço-de-Oliveira R. Mosquitos vetores potenciais de dirofilariose canina na Região Nordeste do Brasil. Rev Saúde Púbica 1999; 33(6):560-65.

2. Casanova, C. Ecologia populacional das fases imaturas de Ochlerotatus scapularis Rondani, 1848 (Diptera: Culicidae) Campinas; [Dissertação de mestrado, Instituto de Biologia da Unicamp] 1994.

3. Casanova, C, Prado, AP. Key-factor analysis of immature stages of Aedes scapularis (Diptera: Culicidae) populations in southeastern Brazil. Bull Ent Res 2002; 92:271-277.

4. Chadee, DD. Laboratory studies of diel oviposition, fecundity, survival, and gonotrophic cycles of Anopheles bellator Dyar and Knab in Trinidad, West Indies. J Vect Ecol 1999; 24(1):83-90.

5. Charlwood, JD, Rafael, JA, Wilkes, TJ. Métodos de determinar a idade fisiológica em Diptera de importância médica. Uma revisão com especial referência aos vetores de doenças na América do Sul. Acta Amazônica 1980; 10 (2):311-333. 
6. Consoli RAGB, Lourenço-de-Oliveira R. Principais mosquitos de importância sanitária no Brasil. Rio de Janeiro: Editora Fiocruz; 1994.

7. Detinova, TS. Age-grading methods in Diptera of medical importance. Geneva, 1962 (WHO - Monographies Series, 47).

8. Detinova, TS. Age grouping methods in Diptera of medical importance. Geneva, WHO, 1968: 13: 427-50.

9. Fernández Z, Forattini OP. Sobrevivência de populações de Aedes albopictus: idade fisiológica e história reprodutiva. São Paulo, Brasil. Rev Saúde Pública $2003 ; 37(3)$ :

10. Forattini, OP. Entomologia Médica v.1. São Paulo: Ed. USP; 1962.

11. Forattini OP, Gomes AC, Galati EAB, Rabello EX, Iverson LB. Estudos ecológicos sobre mosquitos Culicidae no Sistema Serra do Mar, Brasil. 1 Observaçðes no ambiente extradomiciliar. Rev Saúde Púbica 1978a; 12:297325. 
12. Forattini OP, Gomes AC, Galati EAB, Rabello EX, Iverson LB. Estudos ecológicos sobre mosquitos Culicidae no Sistema Serra do Mar, Brasil. 2 Observaçð̃es no ambiente domiciliar. Rev Saúde Púbica 1978b; 12:476-96.

13. Forattini OP, Gomes AC, Santos JLF, Galati EAB, Rabello EX, Natal D. Observaçðes sobre atividade de mosquitos culicidae, em mata residual no Vale do Ribeira, São Paulo Brasil. Rev Saúde Pública 1981;15: 557-86.

14. Forattini OP, Gomes AC, Natal D, Santos JLF. Observações sobre atividade de mosquitos culicidae em matas primitivas da planície e perfis epidemiológicos de vários ambientes no Vale do Ribeira, São Paulo, Brasil. Rev Saúde Pública 1986; 20(3):178-203.

15. Forattini OP, Gomes AC, Natal D, Kakitani I, Marucci D. Preferências alimentares de mosquitos Culicidae no Vale do Ribeira, São Paulo, Brasil. Rev Saúde Pública 1987; 21(3):171-87.

16. Forattini OP, Gomes AC. Biting activity of Aedes scapularis (Rondani) and Haemagogus mosquitoes in Southern Brazil. Rev Saúde Pública 1988.22:84-93.

17. Forattini OP. Ecologia, Epidemiologia e Sociedade. São Paulo: Ed. USP; 1992. 
18. Forattini OP, Kakitani I, Massad E, Marucci D. Studies on mosquitoes (Diptera Culicidae) and anthropic environment. 9 - Synanthropy and epidemiological vector role of Aedes scapularis in South-Eastern Brazil. Rev Saúde Pública, $1995 ; 29: 199-207$

19. Forattini OP, Kakitani I, Sallum MAM. Encontro de criadouros de Aedes scapularis (Diptera: Culicidae) em recipientes artificiais. Rev Saúde Pública 1997;31(5):519-22.

20. Forattini OP, Kakitani I, Santos RLC, Kobayashi KM, Ueno HM e Fernandez Z. Comportamento de Aedes albopictus e de Aedes scapularis adultos (Diptera: Culicidae) no Sudeste do Brasil. Rev Saúde Pública 2000; 34(5):461:7.

21. Forattini, OP. Culicidologia Médica v.2. São Paulo: Ed. USP; 2002.

22. Foster WA. Mosquito sugar feeding and reproductive energetics. Ann Rev Entomol 1995; 40:443-74.

23. Fox AS, Brust RA. How do dilatations form in mosquito ovarioles Parasitol Today $1994 ; 10(1): 19-23$ 
24. Gomes AC, Silva NN, Marques GRAM e Brito M. Host-feeding patterns of potential human disease vectors in the Paraiba Valley Region, State of São Paulo, Brazil. J Vector Ecol 2003; 28(1)74-78.

25. Hien DS. Biology of Aedes aegypti (L., 1762) and Aedes albopictus (Skuse, 1895) Diptera, Culicidae). V. The gonotrophic cycle and oviposition. Acta Parasit Pol, 1976; 24:37-55.

26. Hoc TQ, Charlwood JD Age determination of Aedes cantans using the ovarian oil injection technique. Med Vet Entomol 1990 4:227-33, 1990.

27. Iversson LB. Rocio encephalitis. In: Monath TP, editor. The arboviruses: epidemiology and ecology. Boca Raton: CRC Press, 1989.v4.p77-92.

28. Iversson LB, Rosa APAT da, Rosa MDB. Ocorrência recente de infecção humana por arbovirus Rocio na região do Vale do Ribeira. Rev Inst Me Trop S Paulo, 1989; 31:28-31.

29. Kakitani 1. Observações preliminares sobre a paridade de Anopheles (Kerteszia) cruzii. São Paulo; 1992. [Dissertação de mestrado - Faculdade de Saúde Pública da USP]. 
30. Kakitani I. Paridade e desenvolvimento ovariano de Anopheles albitarsis I.s. Em área de agro-ecossistema irrigado. São Paulo; 1997. [Tese de DoutoradoFaculdade de Saúde Pública da USP].

31. Kakitani I, Ueno, HM, Forattini OP. Paridade e a influência do vento sobre a hematofagia de Anopheles marajoara e freqüencia de Aedes scapularis no Vale do Ribeira, Estado de São Paulo, Brasil (Diptera: Culicidae) Rev de Saúde Pública $2003 ; 37: 280-4$.

32. Kardos EH, Bellamy RE. Distinguishing nulliparos from parous female Culex tarsalis by examination of the ovariam tracheation. Ann Ent Soc Am, 1961 $54: 448-51$

33. Klowden MJ, Briegel $\mathrm{H}$. Mosquito gonotrophic cycle and multiple feeding potential: Contrasts between Anopheles and Aedes (Diptera: Culicidae). J Med Entomol, 1994; 31:618-22.

34. Labarthe N, Serrão, ML, Melo YF, Oliveira, SJ de, Lourenço-de-Oliveira, R. Potential vectors of Dirofilaria immitis (Leidy, 1856) in Itacoatiara, Oceanic Region of Niterói municipality, State of Rio de Janeiro, Brazil. Mem Inst Oswaldo Cruz, 1998; 93(4):425-32. 
35. Lea AO, Briegel H, Lea HM. Arrest, resorption, or maturation of oocytes in Aedes aegypti: dependence on the quantity of blood and the interval between blood meals. Physiol Entomol, 1978; 3:309-316.

36. Lourenço-de-Oliveira R, Deane LM. Presumed Dirofilaria immitis Infections in Wild-Caught Aedes taeniorhynchus and Aedes scapularis in Rio de Janeiro, Brazil. Mem Inst Oswaldo Cruz, 1995; 90(3):387-388.

37. Menezes RMT. Aspectos bioecológicos de Culex quinquefasciatus e Ochlerotatus scapularis, abrigados em habitats do Parque Ecológico do Tietê na cidade de São Paulo, SP. São Paulo; 2002 [Tese de Doutorado - Faculdade de Saúde Pública da USP].

38. Mitchell CJ, Forattini OP. Experimental transmission of Rocio Encephalitis Virus by Aedes scapularis (Diptera: Culicidae) from the epidemic zone in Brazil. J Med Entomol 1984; 21(1):34-37.

39. Mitchell CJ, Forattini OP, Miller BR. Vector competence experiments with Rocio Virus and three mosquito species from the epidemic zone in Brazil. Rev Saúde Pública 1986;20(3):171-7.

40. Nayar JK, Knight JW. Occurrence of ovariolar dilatations in nulliparous mosquitoes: Culex nigripalpus Mosq News 1981; 41(2):281-87. 
41. Nayar JK, Knight JW. Ovarian development in Culex nigripalpus Theobald (Diptera: Culicidae) and its implication to disease transmission. Entomologia exp. appl. 1981 b; 29:49-59.

42. Reinert JF. New classification for the composite genus Aedes (Diptera: Culicidae: Aedini), elevation of subgenus Ochlerotatus to generic rank, reclassification of the other subgenera, and notes on certain subgenera and species. J Am Mosq Control Assoc 2000; 16(3):175-88.

43. Reinert JF. Revised list of abbreviations for genera and subgenera of Culicidae (Diptera) and notes on generic and subgeneric changes. J Am Mosq Control Assoc $2001 ; 17(1): 51-5$.

44. Romano-Lieber NS, Iversson LB. Inquérito soroeidemiológico para pesquisa de infecções por arbovírus em moradores de reserva ecológica. Rev Saúde Pública $2000 ; 34(3): 236-42$.

45. Santos RLC. Medida da capacidade vetorial de Anopheles albitarsis e de Anopheles (Kerteszia) da região sudeste do Brasil. São Paulo; 2001. [Tese de Doutorado - Faculdade de Saúde Pública da Universidade de São Paulo].

46. Secretaria de Estado do Meio Ambiente. Programa de educação ambiental do Vale do Ribeira. São Paulo; 1992 (Série Educação Ambiental). 
47. SEADE - Fundação Sistema Estadual de Análise de Dados - Informações municipais - perfil municipal Disponivel em: URL: <http:www.seade.gov.nr/perfil/index.html>. [2004 Ago 20].

48. Service M. W. Mosquito ecology: field sampling methods. 2. ed. London: Elsevier Applied Science; 1993.

49. Silva, AM, Menezes RMT. Encontro de Aedes scapularis (Diptera: Culicidae) em criadouro artificial em localidade da região Sul do Brasil. Rev Saúde Pública 1996; 30:103-4.

50. Sokolova MI A redescription of the morphology of mosquito (Diptera: Culicidae) ovariolos during vitellogenesis. Bull Soc Vector Ecol 1994; $19(1): 53-68$ 
ANEXOS 
ANEXO 1 - Tabela geral com dados de laboratório

Tabela 1: Anotações sobre todo o ciclo e diagnóstico de condição de paridade segundo a Escola Nova de 100 Oc. scapularis mantidos em laboratório (F1), partir de fêmeas capturadas em Cananéia de janeiro à março de 2004

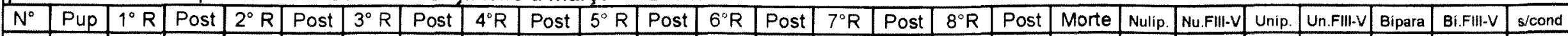

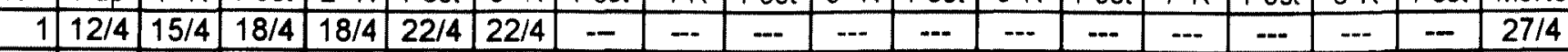

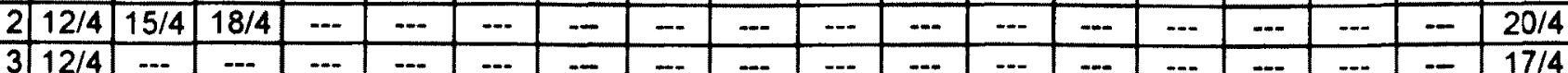

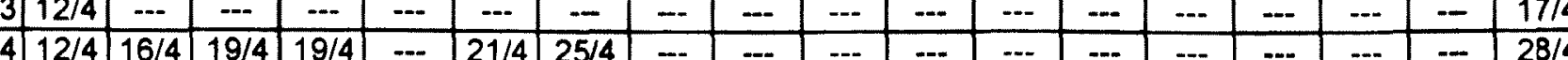

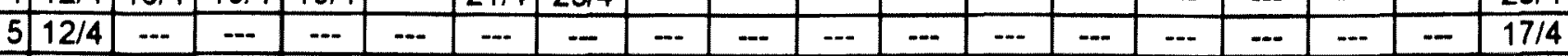

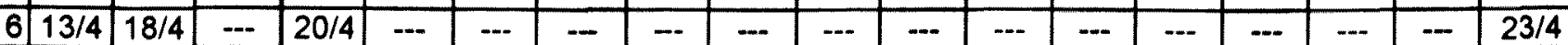

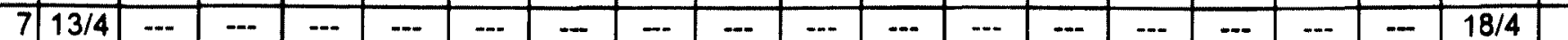

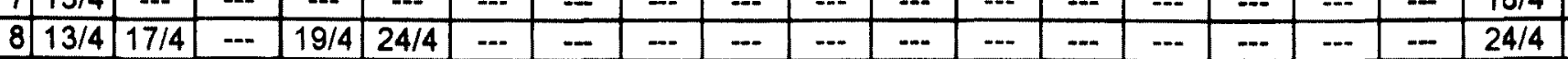

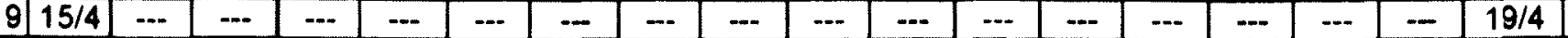

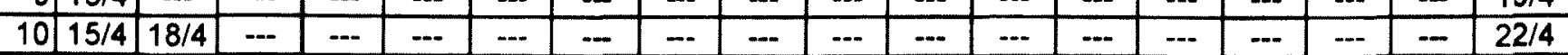

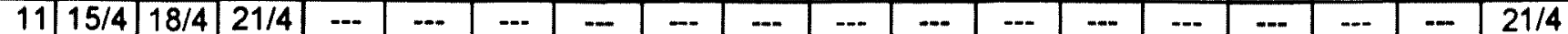

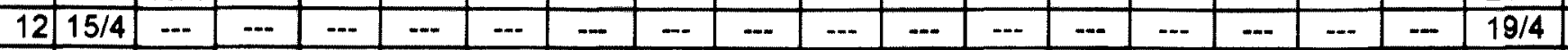

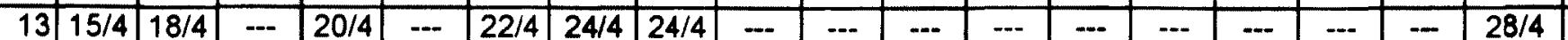

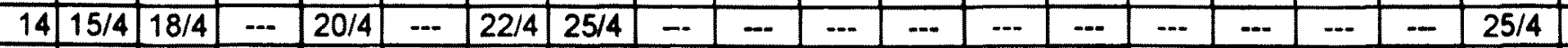

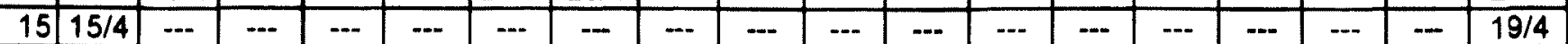

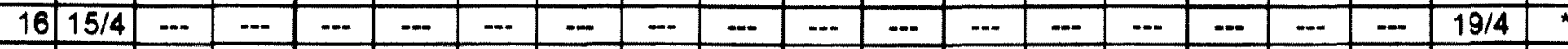

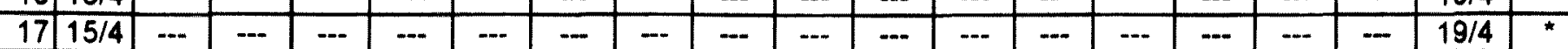

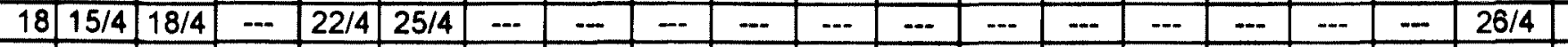

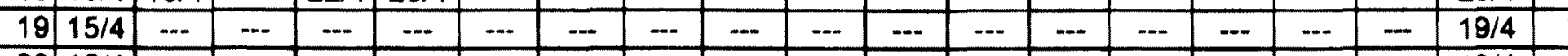

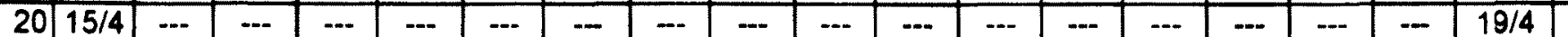

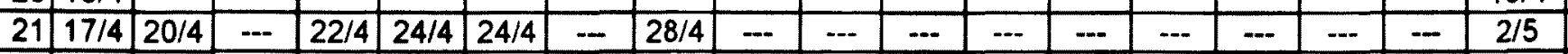

\begin{tabular}{l|l|l|l|l|l|l|l|l|l|l|l|l|l|l|l|l|l|l|}
22 & $17 / 4$ & $20 / 4$ & $\ldots$ & $22 / 4$ & $24 / 4$ & $\ldots$ & $\ldots$ & $\ldots$ & $\ldots$ & $\ldots$ & $\ldots$ & $\ldots$ & $\ldots$ & $\ldots$ & $\ldots$ & $\ldots$ & - & $24 / 4$ \\
\hline
\end{tabular}

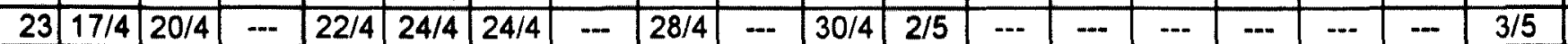

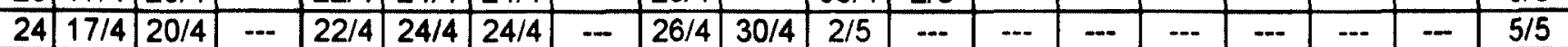

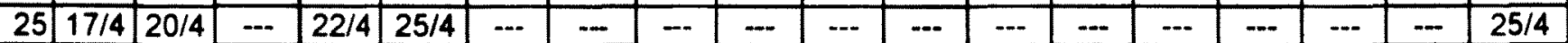

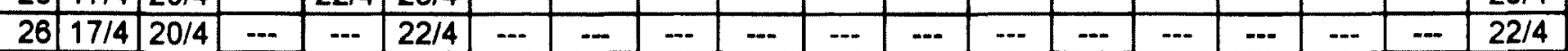

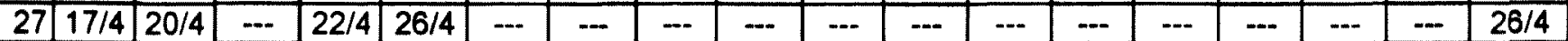

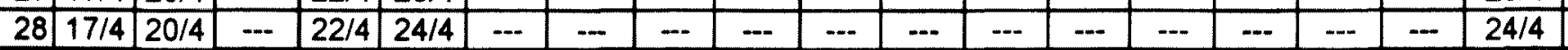

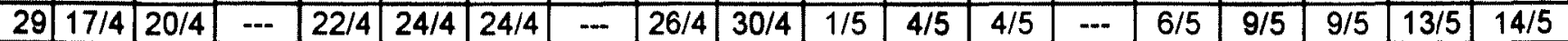

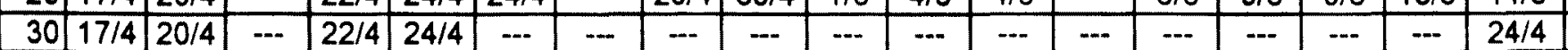

Pupa - data da muda de larva para pupa e montagem da gaiola para o controle da idade das fêmeas

$R=$ data do repasto sangüineo

$P=$ data de postura 


\section{(cont.) Tabela 1}

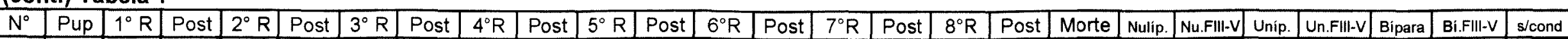

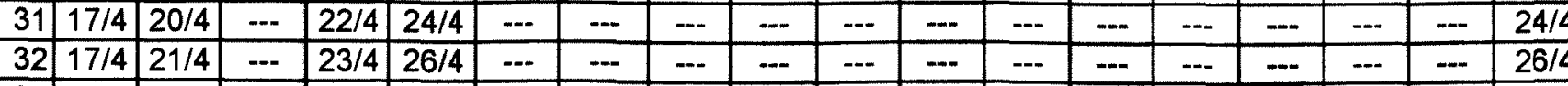

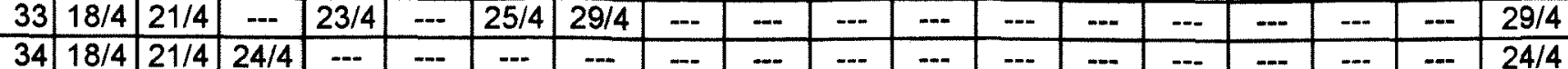

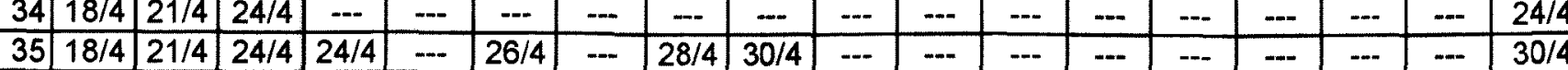

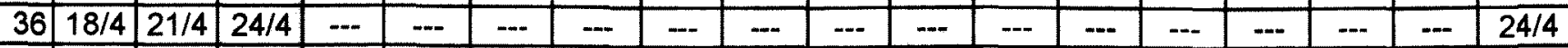

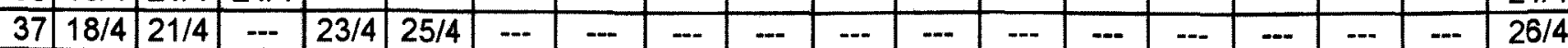

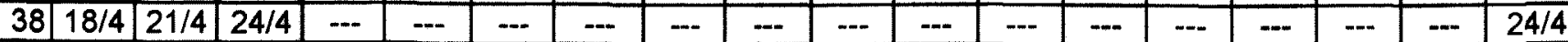

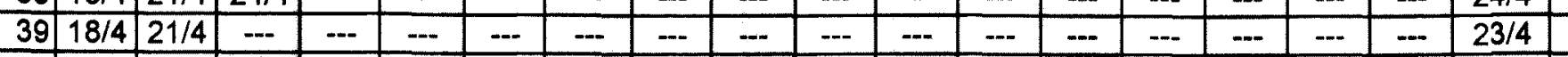

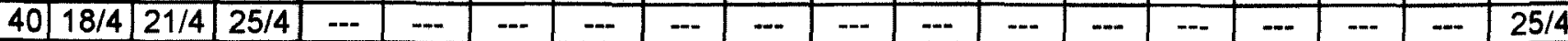

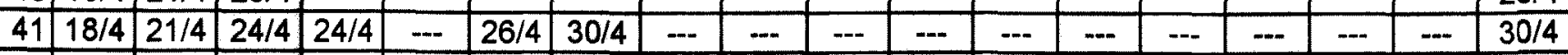

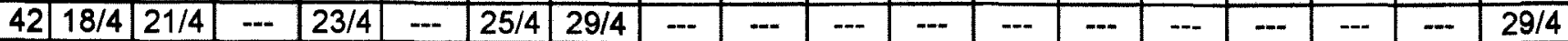

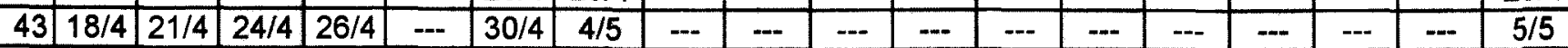

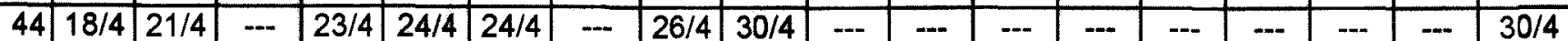

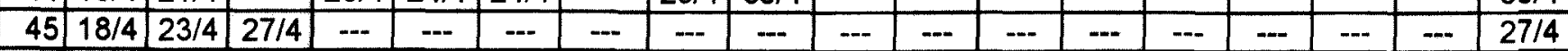

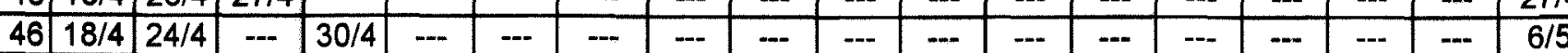

\begin{tabular}{l|l|c|c|c|c|c|c|c|c|c|c|c|c|c|c|c|c|c}
\hline 47 & $18 / 4$ & $23 / 4$ & $26 / 4$ & --- & --- & -- & -- & -- & -- & -- & - & -- & -- & -- & -- & -- & - & $26 / 4$ \\
\hline 48 & $18 / 4$ & $25 / 4$ & -- & $29 / 4$ & --- & $1 / 5$ & -- & $3 / 5$ & $8 / 5$ & -- & -- & --- & --- & --- & -- & -- & -- & $10 / 5$ \\
\hline 49 & $19 / 4$ & $22 / 4$ & $25 / 4$ & - & - & - & - & - & - & - & - & - & - & - & - & - & - & $25 / 4$
\end{tabular}

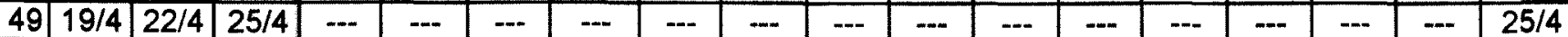

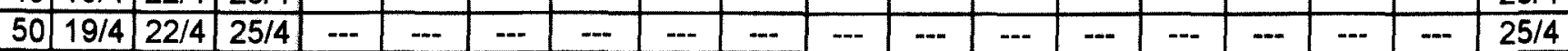

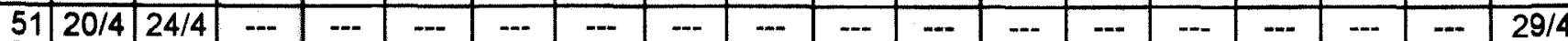

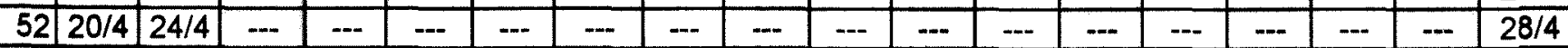

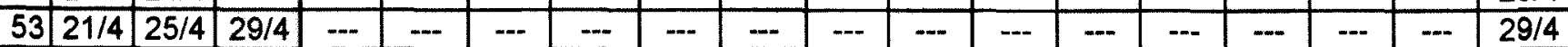

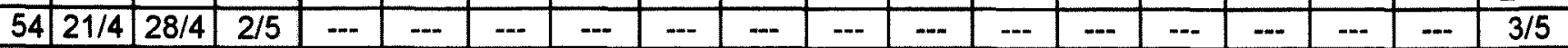

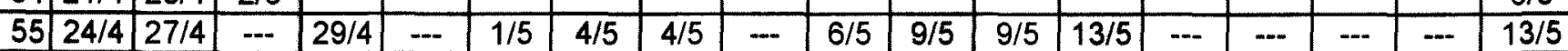

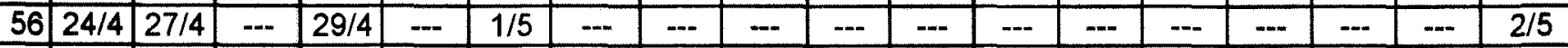

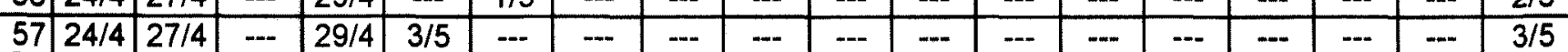

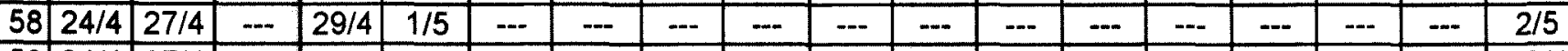

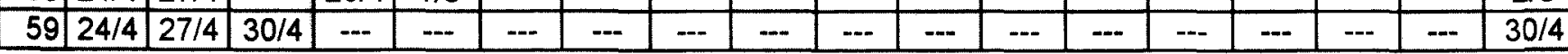

Pupa - data da muda de larva para pupa e montagem da gaiola para o controle da idade das fêmeas

$R=$ data do repasto sangüíneo

$P=$ data de postura 


\begin{tabular}{|c|c|c|c|c|c|c|c|c|c|c|c|c|c|c|c|c|c|c|c|c|c|c|c|c|c|}
\hline \multicolumn{26}{|c|}{ cont.) Tabela 1} \\
\hline $\mathrm{N}^{\circ}$ & Pup & $1^{\circ} \mathrm{R}$ & Post & $2^{\circ} R$ & Post & $3^{\circ} \mathrm{R}$ & Post & $4^{\circ} \mathrm{R}$ & Post & $5^{\circ} \mathrm{R}$ & Post & $6^{\circ} \mathrm{R}$ & Post & $7^{\circ} \mathrm{R}$ & Post & $8^{\circ} \mathrm{R}$ & Post & Morte & Nulip. & Nu.FIII-V & Unip. & Un.FIII.V & Bipara & Bi.FIII-V & s/cond \\
\hline 60 & $24 / 4$ & $28 / 4$ & $-\cdots$ & $\cdots$ & -- & $\ldots$ & $\overline{--}$ & $\ldots$ & -.- & $\ldots$ & $\ldots$ & $\ldots$ & $\ldots$ & $\cdots$ & -.- & $\ldots$ & $\ldots$ & $29 / 4$ & & & & & & & 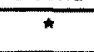 \\
\hline 61 & $24 / 4$ & $28 / 4$ & $2 / 5$ & $\overline{-\cdots}$ & $-\cdots$ & $-\cdots$ & $-\ldots$ & --- & -.. & $-\ldots$ & $-\cdots$ & $\ldots$ & $\ldots$ & $\cdots$ & -..- & $\ldots$ & $\ldots$ & $2 / 5$ & & & * & & & & \\
\hline 62 & $24 / 4$ & $30 / 4$ & $\cdots$ & $\cdots$ & $\cdots$ & $\cdots$ & $\cdots$ & -- & $\cdots$ & $\cdots$ & $\cdots$ & $\cdots$ & $\ldots$ & $\cdots$ & $\cdots$ & $\cdots$ & $\cdots$ & $3 / 5$ & & $\star$ & & & & & \\
\hline 63 & $25 / 4$ & $29 / 4$ & $-\cdots$ & $1 / 5$ & $\ldots$ & $5 / 5$ & $6 / 5$ & $6 / 5$ & --- & -.. & -..- & $\ldots$ & -.- & $\ldots$ & --- & $\ldots$ & - & $10 / 5$ & & * & & & & & \\
\hline 64 & $25 / 4$ & $29 / 4$ & $3 / 5$ & --- & $\ldots$ & $\ldots$ & $\overline{-.-}$ & $\ldots$ & $=-$ & -..- & $\ldots$ & $\ldots$ & $\ldots$ & $\ldots$ & $\ldots$ & $\ldots$ & & $3 / 5$ & & & " & & & & \\
\hline 65 & $25 / 4$ & $29 / 4$ & $-\cdots$ & $1 / 5$ & $\overline{-\cdots}$ & $5 / 5$ & $\ldots$ & $\ldots$ & --- & $\ldots$ & $\ldots$ & ... & $\ldots$ & $\ldots$ & $\ldots$ & $\ldots$ & $\ldots$ & $8 / 5$ & & * & & & & & \\
\hline 66 & $25 / 4$ & $29 / 4$ & $\ldots$ & $3 / 5$ & $4 / 5$ & $4 / 5$ & $7 / 5$ & $7 / 5$ & $10 / 5$ & $10 / 5$ & $-\cdots$ & $12 / 5$ & $14 / 5$ & $\ldots$ & --- & $\ldots$ & 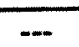 & $14 / 5$ & & & " & & & & \\
\hline 67 & $25 / 4$ & $29 / 4$ & $2 / 5$ & $-\cdots$ & $-\cdots$ & $\ldots$ & $\ldots$ & -.- & $\overline{--}$ & $\ldots$ & $\ldots$ & $\ldots$ & $\overline{---}$ & $\ldots$ & --- & $\ldots$ & -- & $2 / 5$ & & & * & & & & \\
\hline 68 & $25 / 4$ & $29 / 4$ & $\cdots$ & $1 / 5$ & $3 / 5$ & $3 / 5$ & $\ldots$ & $6 / 5$ & $\ldots$ & $8 / 5$ & $10 / 5$ & $10 / 5$ & $\ldots$ & $12 / 5$ & $14 / 5$ & $14 / 5$ & -- & $18 / 5$ & & & & * & & & \\
\hline 69 & $25 / 4$ & $29 / 4$ & $2 / 5$ & $2 / 5$ & $\cdots$ & $-\cdots$ & $\overline{-\cdots}$ & $\ldots$ & -- & $\ldots$ & $\ldots$ & $\ldots$ & $\cdots$ & $\ldots$ & $\ldots$ & $\ldots$ & $\ldots$ & $3 / 5$ & & & " & & & & \\
\hline 70 & $25 / 4$ & $29 / 4$ & $3 / 5$ & $\cdots$ & $\cdots$ & $\ldots$ & $\overline{--}$ & $\ldots$ & --- & $\ldots$ & $\ldots$ & $\ldots$ & $\ldots$ & $\cdots$ & $\ldots$ & $\ldots$ & $\ldots$ & $3 / 5$ & & & * & & & & \\
\hline 71 & $25 / 4$ & $29 / 4$ & $\cdots$ & $1 / 5$ & $3 / 5$ & $\cdots$ & 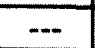 & $\cdots$ & -.- & --- & $\ldots$ & $\ldots$ & $\cdots$ & $\ldots$ & $\ldots$ & $\ldots$ & $\ldots$ & $3 / 5$ & & & * & & & & \\
\hline 72 & $25 / 4$ & $29 / 4$ & $3 / 5$ & -..- & $-\cdots$ & $\cdots$ & -.. & -.- & --- & -.- & $\ldots$ & $\ldots$ & $\ldots$ & $\ldots$ & $\ldots$ & $\cdots$ & $\cdots$ & $3 / 5$ & & & 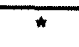 & & & & \\
\hline 73 & $25 / 4$ & $29 / 4$ & $4 / 5$ & $4 / 5$ & 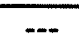 & $6 / 5$ & $9 / 5$ & $9 / 5$ & $\ldots$ & $11 / 5$ & $\ldots$ & $\ldots$ & $\ldots$ & $\cdots$ & -.- & $\cdots$ & --- & $13 / 5$ & & ॠ & & & & & \\
\hline 74 & $25 / 4$ & $29 / 4$ & $\cdots$ & $1 / 5$ & $\ldots$ & $3 / 5$ & $\cdots$ & $5 / 5$ & --- & $7 / 5$ & $\ldots$ & $9 / 5$ & $14 / 5$ & $\ldots$ & --- & $\cdots$ & $\ldots$ & $14 / 5$ & & * & & & & & \\
\hline 75 & $25 / 4$ & $29 / 4$ & $\overline{--}$ & $5 / 5$ & $10 / 5$ & $10 / 5$ & $\ldots$ & $13 / 5$ & -- & $15 / 5$ & $18 / 5$ & --- & $\ldots$ & ..- & --- & ... & $\ldots$ & $18 / 5$ & & & & & & & * \\
\hline 76 & $25 / 4$ & $29 / 4$ & $\cdots$ & $1 / 5$ & $3 / 5$ & $\cdots$ & $\cdots$ & $\cdots$ & -- & $\cdots$ & $\cdots$ & $\cdots$ & $-\cdots$ & $\cdots$ & $\ldots$ & $\ldots$ & $\ldots$ & $3 / 5$ & & & * & & & & \\
\hline 77 & $25 / 4$ & \begin{tabular}{|l|}
$29 / 4$ \\
\end{tabular} & $\cdots$ & $1 / 5$ & $3 / 5$ & $4 / 5$ & $7 / 5$ & $\cdots$ & --- & $\ldots$ & $\ldots$ & $\ldots$ & $\ldots$ & $\ldots$ & $\ldots$ & --- & $\ldots$ & $7 / 5$ & & & & 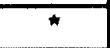 & & & \\
\hline 78 & $25 / 4$ & \begin{tabular}{|l|}
$29 / 4$ \\
\end{tabular} & --- & $1 / 5$ & $4 / 5$ & $\cdots$ & $\ldots$ & $-\cdots$ & -- & -.- & $\ldots$ & $\ldots$ & -.- & -.. & $\ldots$ & $\ldots$ & $\ldots$ & $4 / 5$ & & & * & & & & \\
\hline 79 & $26 / 4$ & $2 / 5$ & $6 / 5$ & $\cdots$ & $\cdots$ & $\ldots$ & $\ldots$ & $\cdots$ & --- & -.- & $\ldots$ & $\cdots$ & $\ldots$ & $\ldots$ & $\ldots$ & --. & -- & $6 / 5$ & & & " & & & & \\
\hline 80 & $26 / 4$ & $2 / 5$ & $5 / 5$ & $5 / 5$ & $9 / 5$ & $9 / 5$ & -.. & $11 / 5$ & $13 / 5$ & $14 / 5$ & $17 / 5$ & $\cdots$ & $\ldots$ & $\ldots$ & $\ldots$ & $\cdots$ & $\cdots$ & $17 / 5$ & & & & \# & & & \\
\hline 81 & $26 / 4$ & $5 / 5$ & $\ldots$ & $\ldots$ & $\cdots$ & $\cdots$ & $\cdots$ & $\cdots$ & -- & $-\cdots$ & $\ldots$ & $\ldots$ & $\ldots$ & -.. & $\ldots$ & $-\ldots$ & $-\cdots$ & $12 / 5$ & & * & & & & & \\
\hline 82 & $26 / 4$ & $4 / 5$ & --- & $6 / 5$ & $8 / 5$ & $-\ldots$ & -- & $\ldots$ & -- & $\cdots$ & $\ldots$ & $\ldots$ & $-\cdots$ & $\cdots$ & $\ldots$ & $\cdots$ & $\cdots$ & $9 / 5$ & & & * & & & & \\
\hline 83 & $26 / 4$ & $4 / 5$ & $8 / 5$ & $\cdots$ & $\cdots$ & $\ldots$ & - & $\ldots$ & $\ldots$ & $\cdots$ & $\ldots$ & $\ldots$ & --- & $\ldots$ & $\ldots$ & $\ldots$ & $\ldots$ & $8 / 5$ & & & & * & & & \\
\hline 84 & $26 / 4$ & \begin{tabular}{|l|}
$5 / 5$ \\
\end{tabular} & -- & $7 / 5$ & $\cdots$ & $9 / 5$ & $11 / 5$ & $11 / 5$ & $15 / 5$ & $15 / 5$ & $\cdots$ & $16 / 5$ & $19 / 5$ & $\ldots$ & $\cdots$ & $\cdots$ & $\cdots$ & $20 / 5$ & & & * & & & & \\
\hline 85 & $26 / 4$ & \begin{tabular}{|l|}
$5 / 5$ \\
\end{tabular} & $\ldots$ & $\cdots$ & $\ldots$ & $\ldots$ & $\ldots$ & $\ldots$ & -.- & $\ldots$ & $\ldots$ & $\ldots$ & $\ldots$ & $\ldots$ & $\ldots$ & $\ldots$ & $\cdots$ & $6 / 5$ & * & & & & & & \\
\hline 86 & $27 / 4$ & \begin{tabular}{|l|}
$2 / 5$ \\
\end{tabular} & $6 / 5$ & $\ldots$ & $\cdots$ & $\cdots$ & $\cdots$ & $\cdots$ & -- & $\cdots$ & $\cdots$ & $\cdots$ & $\cdots$ & $\ldots$ & $\cdots$ & $\cdots$ & -.- & $6 / 5$ & & \# & & & & & \\
\hline 87 & $27 / 4$ & $3 / 5$ & $\cdots$ & $5 / 5$ & $9 / 5$ & $\cdots$ & $\cdots$ & $\ldots$ & $\cdots$ & - & $\cdots$ & $\ldots$ & $\ldots$ & $\cdots$ & $\ldots$ & $\ldots$ & $\ldots$ & $9 / 5$ & & & 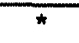 & & & & \\
\hline 88 & $27 / 4$ & $3 / 5$ & -- & $5 / 5$ & $9 / 5$ & $-\cdots$ & $\ldots$ & -.- & 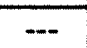 & -.- & $\ldots$ & $\ldots$ & 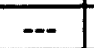 & $\cdots$ & - & -.- & $\ldots$ & $9 / 5$ & & & * & & & & \\
\hline 89 & $27 / 4$ & $2 / 5$ & $6 / 5$ & $6 / 5$ & $\cdots$ & $8 / 5$ & $12 / 5$ & $\cdots$ & $\cdots$ & -- & $\ldots$ & --. & $\overline{-\cdots}$ & $\cdots$ & --. & $\cdots$ & $\cdots$ & $12 / 5$ & & & & & & & \\
\hline
\end{tabular}

Pupa - data da muda de larva para pupa e montagem da gaiola para o controle da idade das fêmeas

$R=$ data do repasto sanguineo

$P=$ data de postura 


\section{(cont.) Tabela 1}

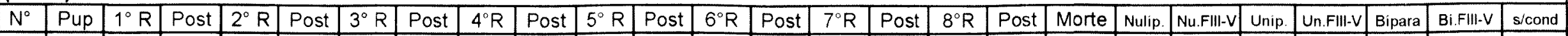
\begin{tabular}{|l|l|l|l|l|l|l|l|l|l|l|l|l|l|l|l|l|l|l}
\hline 90 & $27 / 4$ & $2 / 5$ & $\ldots$ & $4 / 5$ & $7 / 5$ & $7 / 5$ & $\ldots$ & $9 / 5$ & $14 / 5$ & $\ldots$ & $\ldots$ & $\ldots$ & $\ldots$ & $\ldots$ & $\ldots$ & $\ldots$ & $\ldots$ & $14 / 5$ \\
\hline
\end{tabular}

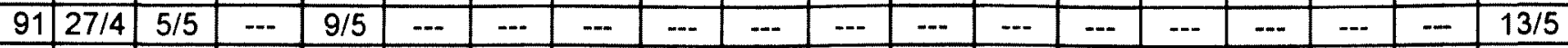

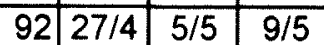

93 27/4 $5 / 5$

94 27/4 $2 / 5$

95 27/4 $4 / 5$

$96-27 / 4 \quad 2 / 5$

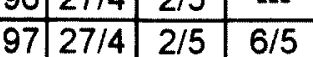

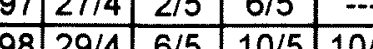

\begin{tabular}{l|l|l|l|l|l}
98 & $29 / 4$ & $6 / 5$ & $10 / 5$ & $10 / 5$ \\
\hline 99 & $29 / 4$ & $6 / 5$ & & &
\end{tabular}

\begin{tabular}{l|l|l|l|}
100 & $29 / 4$ & $6 / 5$ \\
\hline
\end{tabular}

Pupa - data da muda de larva para pupa e montagem da gaiola para o controle da idade das fêmeas

$R$ = data do repasto sangüíneo

$P=$ data de postura 


\begin{tabular}{|c|c|c|c|c|c|c|c|c|c|c|c|c|c|}
\hline $\mathrm{N}^{\circ}$ & $1^{*}$ Ovip & Quant. & $2^{\circ}$ Ovip & Quant. & $3^{a}$ Ovip & Quant. & $4^{a}$ Ovip & Quant. & $5^{\circ}$ Ovip & Quant. & $6^{a}$ Ovip & Quant. & Total \\
\hline 1 & $18 / 4$ & 165 & $22 / 4$ & 53 & - & -- & - & - & - & - & $=$ & -- & 218 \\
\hline 2 & $18 / 4$ & 103 & - & - & - & $\ldots$ & - & -- & - & - & - & $\cdots$ & 103 \\
\hline 3 & - & - & $=$ & - & - & -- & - & -- & $=$ & - & - & -- & 0 \\
\hline 4 & $19 / 4$ & 118 & $25 / 4$ & 2 & - & - & - & - & - & - & - & - & 120 \\
\hline 5 & - & - & - & - & - & -- & - & -- & $=$ & - & - & -- & 0 \\
\hline 6 & - & - & - & $\ldots$ & - & - & - & - & - & - & - & -- & 0 \\
\hline 7 & - & - & - & -- & - & -- & - & - & $=$ & -- & - & - & 0 \\
\hline 8 & $24 / 4$ & 2 & - & $\ldots$ & - & -- & - & - & - & - & - & - & 2 \\
\hline 9 & - & - & - & - & - & - & - & - & - & $\ldots$ & - & - & 0 \\
\hline 10 & - & - & - & -- & - & -- & - & $\ldots$ & - & - & - & - & 0 \\
\hline 11 & $21 / 4$ & 39 & - & -- & - & - & - & -- & - & - & - & -- & 39 \\
\hline 12 & - & - & - & - & - & -- & - & - & - & -- & - & - & 0 \\
\hline 13 & $24 / 4$ & 78 & - & - & - & -- & - & - & - & -- & - & $\cdots$ & 78 \\
\hline 14 & $25 / 4$ & 3 & - & -- & - & - & - & - & - & - & - & $\ldots$ & 3 \\
\hline 15 & - & - & - & - & - & - & - & - & - & -- & - & -. & 0 \\
\hline 16 & - & - & - & -- & - & - & - & - & - & - & - & - & 0 \\
\hline 17 & - & - & - & - & - & - & - & - & - & -- & - & -. & 0 \\
\hline 18 & $25 / 4$ & 145 & - & -- & - & - & - & -- & - & -- & - & -- & 145 \\
\hline 19 & - & -- & - & -- & - & - & - & - & - & 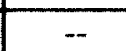 & - & $=$ & 0 \\
\hline 20 & - & - & - & -- & - & - & $=$ & -- & - & -- & - & -- & 0 \\
\hline 21 & $24 / 4$ & 66 & - & - & - & - & - & - & - & - & $=$ & -- & 66 \\
\hline 22 & $24 / 4$ & 61 & - & - & - & - & $=$ & - & - & - & $=$ & $-\cdots$ & 61 \\
\hline 23 & $24 / 4$ & 50 & $2 / 5$ & 45 & - & - & - & - & - & - & - & - & 95 \\
\hline 24 & $24 / 4$ & 75 & $30 / 4$ & 25 & - & - & $=$ & -- & - & - & - & - & 100 \\
\hline 25 & $25 / 4$ & 76 & - & - & - & -- & - & -- & - & -- & - & -- & 76 \\
\hline 26 & $22 / 4$ & 3 & - & -- & - & - & - & $\ldots$ & - & - & - & -- & 3 \\
\hline 27 & $26 / 4$ & 10 & - & - & - & -- & - & - & $=$ & - & - & - & 10 \\
\hline 28 & $24 / 4$ & 76 & - & $\ldots$ & - & - & - & - & - & -- & - & - & 76 \\
\hline 29 & $24 / 4$ & 38 & $30 / 4$ & 93 & $4 / 5$ & 84 & $9 / 5$ & 66 & $13 / 5$ & 101 & - & -- & 382 \\
\hline 30 & $24 / 4$ & 53 & - & -- & - & -- & - & - & - & $\ldots$ & - & -- & 53 \\
\hline
\end{tabular}




\begin{tabular}{|c|c|c|c|c|c|c|c|c|c|c|c|c|c|}
\hline \multicolumn{14}{|c|}{ (cont.) Tabela 3} \\
\hline$N^{\circ}$ ? & $1^{\circ}$ Ovip & Quant. & $2^{\circ}$ Ovip & Quant. & $3^{\circ}$ Ovip & Quant. & $4^{9}$ Ovip & Quant & $5^{\circ}$ Ovip & Quant. & $6^{2}$ Ovip & Quant. & Total \\
\hline 31 & $24 / 4$ & 72 & - & - & - & -- & - & - & - & -- & - & -- & 72 \\
\hline 32 & $26 / 4$ & 1 & - & $\ldots$ & - & - & $=$ & - & $=$ & - & - & - & 1 \\
\hline 33 & $29 / 4$ & 8 & $=$ & $\cdots$ & - & - & - & - & - & $\cdots$ & $=$ & - & 8 \\
\hline 34 & $24 / 4$ & 102 & - & -- & - & - & - & - & - & - & - & - & 102 \\
\hline 35 & $24 / 4$ & 106 & $30 / 4$ & 16 & - & - & - & $\cdots$ & $=$ & $\cdots$ & - & - & 122 \\
\hline 36 & $24 / 4$ & 40 & $=$ & -- & - & -- & - & - & - & -- & $=$ & -- & 40 \\
\hline 37 & $25 / 4$ & 106 & - & $\cdots$ & $=$ & - & - & $\cdots$ & - & - & - & -- & 106 \\
\hline 38 & $24 / 4$ & 85 & - & - & - & - & $=$ & - & $=$ & - & - & - & 85 \\
\hline 39 & - & -- & $=$ & $\cdots$ & - & -- & - & $-\cdots$ & $=$ & - & - & - & 0 \\
\hline 40 & $25 / 4$ & 7 & - & -- & - & - & - & - & - & - & $=$ & - & 7 \\
\hline 41 & $24 / 4$ & 72 & $30 / 4$ & 73 & - & - & - & $-\cdots$ & - & $\cdots$ & - & - & 145 \\
\hline 42 & $29 / 4$ & 149 & - & $\cdots$ & - & $\cdots$ & $=$ & $\ldots$ & $=$ & - & $=$ & $\ldots$ & 149 \\
\hline 43 & $24 / 4$ & 127 & $4 / 5$ & 83 & - & - & - & $-\cdots$ & - & -- & - & -- & 210 \\
\hline 44 & $24 / 4$ & 103 & $30 / 4$ & 2 & - & - & - & - & - & - & $=$ & -- & 105 \\
\hline 45 & $27 / 4$ & 49 & - & -- & - & - & - & -- & - & $\cdots$ & - & -- & 49 \\
\hline 46 & - & $\ldots$ & - & $\ldots$ & - & -- & - & $\ldots$ & $=$ & $\ldots$ & - & $\ldots$ & 0 \\
\hline 47 & $26 / 4$ & 121 & - & -- & - & - & - & -- & $=$ & -- & - & -- & 121 \\
\hline 48 & $8 / 5$ & 3 & - & - & - & - & - & $\cdots$ & - & - & - & - & 3 \\
\hline 49 & $25 / 4$ & 34 & - & -- & $=$ & - & - & - & - & - & - & - & 34 \\
\hline 50 & $25 / 4$ & 36 & - & - & - & - & - & - & - & - & - & - & 36 \\
\hline 51 & - & $\cdots$ & - & -- & - & -- & - & - & - & $\cdots$ & - & - & 0 \\
\hline 52 & - & $\cdots$ & - & - & - & - & - & - & - & $\ldots$ & - & $\cdots$ & 0 \\
\hline 53 & $29 / 4$ & 155 & - & - & - & -- & $=$ & $\cdots$ & $=$ & - & $=$ & - & 155 \\
\hline 54 & $2 / 5$ & 75 & - & - & - & -- & - & $\cdots$ & $=$ & -- & - & -- & 75 \\
\hline 55 & $4 / 5$ & 40 & $9 / 5$ & 39 & $13 / 5$ & 66 & $=$ & - & - & - & $=$ & -- & 145 \\
\hline 56 & - & $\cdots$ & - & - & - & -- & - & $\cdots$ & - & - & - & -- & 0 \\
\hline 57 & $3 / 5$ & 77 & $=$ & - & $=$ & -- & - & -- & - & - & - & - & 77 \\
\hline 58 & $1 / 5$ & 61 & $=$ & $\ldots$ & - & + & - & - & $=$ & $\ldots$ & $=$ & -- & 61 \\
\hline 59 & $30 / 4$ & 101 & - & - & - & -- & - & $\cdots$ & - & - & - & -- & 101 \\
\hline 60 & - & -- & - & -- & - & - & $=$ & - & - & - & $=$ & $\cdots$ & 0 \\
\hline
\end{tabular}




\begin{tabular}{|c|c|c|c|c|c|c|c|c|c|c|c|c|c|}
\hline \multicolumn{14}{|c|}{ (cont.) Tabela 3} \\
\hline $\mathrm{N}^{\circ}$ & 1 Ovip & Quant & 2 Ovip & Quant & $3^{\circ}$ Ovip & Quant & 4"Ovip & Quant & $5^{*}$ Ovip & Quant. & 6" Ovip & Quant & Total \\
\hline 61 & 215 & 102 & - & $\cdots$ & - & - & - & - & $=$ & - & - & $\sim$ & 102 \\
\hline 62 & $=$ & - & - & $\cdots$ & $=$ & - & $=$ & $\cdots$ & - & - & - & - & 0 \\
\hline 63 & $6 / 5$ & 6 & - & $\cdots$ & - & - & - & $-\cdots$ & - & - & - & -- & 6 \\
\hline 64 & $3 / 5$ & 66 & - & - & $=$ & - & $=$ & - & - & - & - & - & 66 \\
\hline 65 & - & $\cdots$ & - & $\cdots$ & - & -- & - & - & - & $\cdots$ & - & - & 0 \\
\hline 66 & 475 & 83 & 715 & 102 & 1015 & 94 & $14 / 5$ & 58 & $=$ & 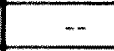 & - & - & 337 \\
\hline 67 & 215 & 112 & - & $\cdots$ & $=$ & - & - & $\cdots$ & $=$ & $\cdots$ & - & - & 112 \\
\hline 68 & $3 / 5$ & 126 & $10 / 5$ & 56 & $14 / 5$ & 19 & - & $\cdots$ & - & - & $=$ & - & 201 \\
\hline 69 & 215 & 79 & - & - & - & - & - & - & - & - & - & - & 79 \\
\hline 70 & $3 / 5$ & 124 & $=$ & $\cdots$ & $=$ & - & - & $\cdots$ & - & $\cdots$ & - & $\cdots$ & 124 \\
\hline 71 & $3 / 5$ & 87 & - & - & - & -- & - & $\cdots$ & - & $\cdots$ & $=$ & $\cdots$ & 87 \\
\hline 72 & $3 / 5$ & 89 & - & - & - & -- & - & $\cdots$ & - & - & - & $\ldots$ & 89 \\
\hline 73 & $4 / 5$ & 74 & 915 & 81 & - & - & $=$ & - & - & - & $=$ & - & 155 \\
\hline 74 & $14 / 5$ & 39 & - & - & - & - & - & $\cdots$ & - & - & - & $\cdots$ & 39 \\
\hline 75 & $10 / 5$ & 65 & 1815 & 72 & - & - & - & - & - & - & - & - & 137 \\
\hline 76 & $3 / 5$ & 91 & - & - & - & -- & - & - & - & - & $=$ & $\ldots$ & 91 \\
\hline 77 & $3 / 5$ & 87 & 715 & 67 & - & -- & $=$ & $\cdots$ & - & - & - & $-\cdots$ & 154 \\
\hline 78 & $4 / 5$ & 121 & - & - & - & -- & - & $\ldots$ & - & $\cdots$ & - & $\ldots$ & 121 \\
\hline 79 & $6 / 5$ & 110 & - & - & - & - & - & $\cdots$ & - & - & $=$ & $\cdots$ & 110 \\
\hline 80 & $5 / 5$ & 45 & 915 & 19 & $13 / 5$ & 22 & $17 / 5$ & 59 & - & - & - & $\cdots$ & 145 \\
\hline 81 & $=$ & - & $=$ & - & - & - & - & - & - & -- & - & - & 0 \\
\hline 82 & $8 / 5$ & 71 & - & - & - & - & - & - & - & - & $=$ & $\cdots$ & 71 \\
\hline 83 & $8 / 5$ & 81 & - & - & - & - & $=$ & - & - & - & - & $\cdots$ & 81 \\
\hline 84 & $11 / 5$ & 13 & 1515 & 88 & $19 / 5$ & 74 & - & -- & - & - & - & $\cdots$ & 175 \\
\hline 85 & - & - & - & $\cdots$ & - & - & $=$ & - & - & - & - & $\cdots$ & 0 \\
\hline 86 & $6 / 5$ & 39 & - & $\cdots$ & - & - & - & - & - & - & - & $\cdots$ & 39 \\
\hline 87 & $9 / 5$ & 85 & - & $\cdots$ & $=$ & - & $=$ & - & $=$ & - & - & $\ldots$ & 85 \\
\hline 88 & $9 / 5$ & 121 & - & - & - & - & - & - & - & - & - & $\cdots$ & 121 \\
\hline 89 & $6 / 5$ & 98 & $12 / 5$ & 92 & - & - & - & - & - & -- & - & $\cdots$ & 190 \\
\hline 90 & $7 / 5$ & 113 & $14 / 5$ & 161 & - & -- & - & - & - & - & $=$ & $\cdots$ & 274 \\
\hline
\end{tabular}




\begin{tabular}{|c|c|c|c|c|c|c|c|c|c|c|c|c|c|}
\hline \multicolumn{14}{|c|}{ (cont.) Tabela 3} \\
\hline $\mathrm{N}^{0}$ & 190vip & Quant. & $2^{\mathrm{a}}$ Ovip & Quant. & $3^{\circ}$ Ovip & Quant. & $4^{\circ}$ Ovip & Quant. & $55^{a}$ Ovip & Quant & $6^{\circ}$ Ovip & Quant. & Total \\
\hline 91 & - & - & $=$ & - & $=$ & - & - & - & $=$ & - & $=$ & - & $\overline{0}$ \\
\hline 92 & 915 & 109 & - & - & $=$ & -. & - & - & $=$ & - & $=$ & -- & 109 \\
\hline 93 & $=$ & - & $=$ & - & $=$ & - & $\bar{z}+x+1+1$ & $=$ & $\bar{z}$ & - & - & - & o \\
\hline 94 & 715 & 68 & - & - & - & -- & - & -- & $\overline{-}$ & -- & - & - & 68 \\
\hline 95 & - & -. & - & - & - & - & - & -- & - & - & - & - & 0 \\
\hline 96 & 715 & 107 & 1015 & 59 & $=$ & -- & $=$ & - & $=$ & - & $=$ & - & 166 \\
\hline 97 & 6/5 & 79 & - & - & $=$ & -- & - & - & $=$ & - & $=$ & -- & 79 \\
\hline 98 & $10 / 5$ & 62 & - & - & $=$ & - & $=$ & -- & - & - & $=$ & -- & 62 \\
\hline 99 & $=$ & - & - & - & - & - & $=$ & $\overline{-}$ & - & - & - & - & 0 \\
\hline 100 & 1115 & 84 & $15 / 5$ & 42 & $18 / 5$ & 90 & $=$ & - & $=$ & $\ldots$ & - & -- & 216 \\
\hline
\end{tabular}




\begin{tabular}{|c|c|c|c|c|c|c|c|c|c|c|c|c|c|}
\hline \multicolumn{14}{|c|}{$\begin{array}{l}\text { Qudadro 1: Data de oviposiçá e número de ovos colocados por fémeas de Oc. scapularis mantidadas em labora- } \\
\text { tório (F1). }\end{array}$} \\
\hline $\mathrm{N}^{\circ}$ 이 & $1^{\circ}$ Ovip & Quant. & 2" Ovip & Quant. & $3^{\circ}$ Ovip & Quant. & $4^{\circ}$ Ovip & Quant. & $5^{\circ}$ Ovip & Quant. & $6^{\circ}$ Ovip & Quant. & Total \\
\hline 1 & $18 / 4$ & 165 & $22 / 4$ & 53 & - & - & - & - & - & - & - & - & 218 \\
\hline 2 & $18 / 4$ & 103 & - & - & - & - & - & - & - & - & - & $=$ & 103 \\
\hline 3 & - & - & - & - & - & - & - & - & - & - & - & - & 0 \\
\hline 4 & $19 / 4$ & 118 & $25 / 4$ & 2 & - & - & - & - & - & - & - & - & 120 \\
\hline 5 & - & - & - & - & - & - & - & - & - & - & - & - & 0 \\
\hline 6 & - & - & - & - & - & - & - & - & - & - & - & - & 0 \\
\hline 7 & - & - & - & - & - & - & - & - & - & - & - & - & 0 \\
\hline 8 & $24 / 4$ & 2 & - & - & - & - & - & - & - & - & - & - & 2 \\
\hline 9 & - & - & - & - & - & - & - & - & - & - & - & - & 0 \\
\hline 10 & - & - & - & - & - & - & - & - & - & - & - & - & 0 \\
\hline 11 & $21 / 4$ & 39 & - & - & - & - & $=$ & - & - & - & - & - & 39 \\
\hline 12 & - & - & - & - & - & - & - & - & - & - & - & - & 0 \\
\hline 13 & $24 / 4$ & 78 & - & - & - & - & - & - & - & - & - & - & 78 \\
\hline 14 & $25 / 4$ & 3 & - & - & - & - & - & $\overline{-}$ & $=$ & - & - & - & 3 \\
\hline 15 & - & - & - & - & - & - & - & - & - & - & - & - & 0 \\
\hline 16 & - & - & - & - & - & - & - & - & - & - & - & - & 0 \\
\hline 17 & - & - & - & - & $=$ & - & - & - & - & - & - & - & 0 \\
\hline 18 & $25 / 4$ & 145 & - & - & - & - & - & - & $=$ & - & - & - & 145 \\
\hline 19 & - & - & - & - & - & - & - & - & - & - & - & - & 0 \\
\hline 20 & - & - & - & - & - & - & - & - & - & - & - & - & 0 \\
\hline 21 & $24 / 4$ & 66 & - & - & - & - & - & - & - & - & - & - & 66 \\
\hline 22 & $24 / 4$ & 61 & - & - & - & - & - & - & - & - & - & - & 61 \\
\hline 23 & $24 / 4$ & 50 & $2 / 5$ & 45 & - & - & - & - & - & - & - & - & 95 \\
\hline 24 & $24 / 4$ & 75 & $30 / 4$ & 25 & - & - & - & - & - & - & - & - & 100 \\
\hline 25 & $25 / 4$ & 76 & - & - & - & - & - & - & - & - & - & - & 76 \\
\hline 26 & $22 / 4$ & 3 & - & - & $=$ & - & - & - & - & $=$ & - & - & 3 \\
\hline 27 & $26 / 4$ & 10 & - & - & - & - & - & - & - & - & - & - & 10 \\
\hline 28 & $24 / 4$ & 76 & - & - & - & - & - & - & - & $=$ & - & - & 76 \\
\hline 29 & $24 / 4$ & 38 & $30 / 4$ & 93 & $4 / 5$ & 84 & $9 / 5$ & 66 & $13 / 5$ & 101 & - & - & 382 \\
\hline 30 & $24 / 4$ & 53 & - & - & - & - & - & - & - & - & - & - & 53 \\
\hline
\end{tabular}




\begin{tabular}{|c|c|c|c|c|c|c|c|c|c|c|c|c|c|}
\hline \multicolumn{14}{|c|}{ (cont) Quadro 1} \\
\hline$N^{\circ} 9$ & 1 Ovip & Quent. & $2^{n}$ Ovip & Quant. & $3^{\circ}$ Ovip & Quant. & $4^{\circ}$ Ovip & Quant. & $5^{\circ}$ Ovip & Quant. & $6^{\circ}$ Ovip & Quant. & Total \\
\hline 31 & $24 / 4$ & 72 & - & - & - & - & - & - & - & - & - & - & 72 \\
\hline 32 & $26 / 4$ & 1 & - & - & - & - & - & - & - & - & - & - & 1 \\
\hline 33 & $29 / 4$ & 8 & $=$ & - & - & - & - & - & - & - & - & - & 8 \\
\hline 34 & $24 / 4$ & 102 & - & - & - & - & - & - & - & - & - & - & 102 \\
\hline 35 & $24 / 4$ & 106 & $30 / 4$ & 16 & - & - & - & - & - & - & - & - & 122 \\
\hline 36 & $24 / 4$ & 40 & - & - & - & - & - & - & - & - & - & - & 40 \\
\hline 37 & $25 / 4$ & 106 & - & - & - & - & - & - & - & - & - & - & 106 \\
\hline 38 & $24 / 4$ & 85 & - & - & - & - & - & - & - & - & - & - & 85 \\
\hline 39 & - & - & - & - & - & - & - & - & - & - & - & - & 0 \\
\hline 40 & $25 / 4$ & 7 & - & - & - & - & - & - & $=$ & - & - & - & 7 \\
\hline 41 & $24 / 4$ & 72 & $30 / 4$ & 73 & - & - & - & - & - & - & - & - & 145 \\
\hline 42 & $29 / 4$ & 149 & - & - & - & - & - & - & - & - & - & - & 149 \\
\hline 43 & $24 / 4$ & 127 & $4 / 5$ & 83 & - & - & - & - & - & - & - & - & 210 \\
\hline 44 & $24 / 4$ & 103 & $30 / 4$ & 2 & - & - & - & - & - & - & - & - & 105 \\
\hline 45 & $27 / 4$ & 49 & - & - & $=$ & - & - & - & - & - & - & $=$ & 49 \\
\hline 46 & - & - & - & - & - & - & - & - & - & - & - & - & 0 \\
\hline 47 & $26 / 4$ & 121 & - & - & - & - & - & - & - & - & - & - & 121 \\
\hline 48 & $8 / 5$ & 3 & - & - & - & - & - & - & - & - & - & - & 3 \\
\hline 49 & $25 / 4$ & 34 & - & - & - & - & - & - & - & - & - & - & 34 \\
\hline 50 & $25 / 4$ & 36 & - & - & - & - & - & - & - & - & - & - & 36 \\
\hline 51 & - & - & - & - & $=$ & - & $=$ & - & - & - & - & - & 0 \\
\hline 52 & - & - & - & - & $=$ & - & - & - & - & - & - & - & 0 \\
\hline 53 & $29 / 4$ & 155 & - & - & - & - & - & - & - & - & - & $\overline{-}$ & 155 \\
\hline 54 & $2 / 5$ & 75 & - & - & - & - & - & - & - & - & - & - & 75 \\
\hline 55 & $4 / 5$ & 40 & $9 / 5$ & 39 & $13 / 5$ & 66 & - & - & - & - & - & - & 145 \\
\hline 56 & - & - & - & - & - & - & - & - & - & - & - & - & 0 \\
\hline 57 & $3 / 5$ & 77 & - & - & - & - & - & - & - & - & - & - & 77 \\
\hline 58 & $1 / 5$ & 61 & - & - & - & $=$ & - & - & - & - & - & - & 61 \\
\hline 59 & $30 / 4$ & 101 & - & - & $=$ & - & - & - & - & - & - & - & 101 \\
\hline 60 & - & - & - & - & - & - & - & - & - & - & - & - & 0 \\
\hline
\end{tabular}




\begin{tabular}{|c|c|c|c|c|c|c|c|c|c|c|c|c|c|}
\hline \multirow{2}{*}{\multicolumn{14}{|c|}{ 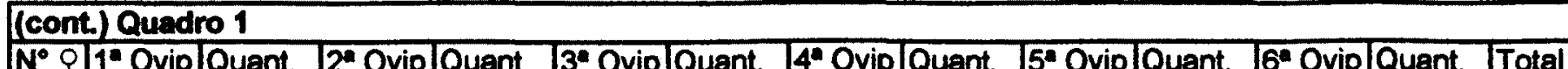 }} \\
\hline & & Quant. & $2^{n}$ Ovip & Quant. & $3^{\circ}$ Ovip & Quant. & $4^{\circ}$ Ovip & Quant. & $5^{2}$ Ovip & Quant. & $6^{a}$ Ovip & Quant. & Total \\
\hline 61 & $2 / 5$ & 102 & - & $\overline{-}$ & $\overline{-}$ & - & - & - & - & - & - & - & 102 \\
\hline 62 & - & - & - & $\overline{-}$ & $\overline{-}$ & $\overline{-}$ & - & - & $\overline{-}$ & - & - & - & $\overline{0}$ \\
\hline 63 & $6 / 5$ & 6 & - & - & $\overline{-}$ & $\overline{-}$ & $=$ & $\overline{-}$ & - & $\overline{-}$ & - & - & 6 \\
\hline 64 & $3 / 5$ & 66 & - & - & $\overline{-}$ & - & - & $=$ & - & - & - & $=$ & 66 \\
\hline 65 & - & - & - & $=$ & $\overline{-}$ & - & - & $\overline{-}$ & - & - & - & - & 0 \\
\hline 66 & $4 / 5$ & 83 & $7 / 5$ & 102 & $10 / 5$ & $\overline{94}$ & $14 / 5$ & 58 & $\overline{-}$ & $\overline{-}$ & - & $\overline{-}$ & 337 \\
\hline 67 & $2 / 5$ & 112 & - & $\overline{-}$ & $\overline{-}$ & $\overline{-}$ & - & - & - & - & - & - & 112 \\
\hline 68 & $3 / 5$ & 126 & $10 / 5$ & 56 & $14 / 5$ & 19 & $=$ & - & $\overline{-}$ & - & $\overline{-}$ & - & 201 \\
\hline 69 & $2 / 5$ & 79 & - & - & - & - & - & - & - & - & - & $=$ & 79 \\
\hline 70 & $3 / 5$ & 124 & $\overline{-}$ & - & - & - & - & - & - & - & - & - & 124 \\
\hline 71 & $3 / 5$ & 87 & - & - & - & - & - & - & - & - & - & - & 87 \\
\hline 72 & $3 / 5$ & 89 & $\overline{-}$ & $\overline{-}$ & - & - & - & - & - & $\overline{-}$ & $\overline{-}$ & $\overline{-}$ & 89 \\
\hline 73 & $4 / 5$ & 74 & $9 / 5$ & 81 & - & - & $\overline{-}$ & $\overline{-}$ & - & $\overline{-}$ & $\overline{-}$ & $\overline{-}$ & 155 \\
\hline 74 & $14 / 5$ & 39 & - & - & - & - & - & - & - & - & - & - & 39 \\
\hline 75 & $10 / 5$ & 65 & $18 / 5$ & 72 & $\overline{-}$ & $=$ & - & - & $=$ & - & - & - & 137 \\
\hline 76 & $3 / 5$ & 91 & - & - & $=$ & - & $\overline{-}$ & $\overline{-}$ & $=$ & $\overline{-}$ & - & - & 91 \\
\hline 77 & $3 / 5$ & 87 & $7 / 5$ & 67 & - & - & - & - & - & - & - & - & 154 \\
\hline 78 & $4 / 5$ & 121 & - & $=$ & - & - & $\overline{-}$ & $\overline{-}$ & - & $\overline{-}$ & - & - & 121 \\
\hline 79 & $6 / 5$ & 110 & $\overline{-}$ & $\overline{-}$ & $\overline{-}$ & $\overline{-}$ & $\overline{-}$ & $\overline{-}$ & - & $\overline{-}$ & $\overline{-}$ & $\overline{-}$ & 110 \\
\hline 80 & $5 / 5$ & 45 & $9 / 5$ & 19 & $13 / 5$ & $\overline{22}$ & $17 / 5$ & 59 & - & - & - & - & 145 \\
\hline 81 & - & - & - & - & - & - & - & - & $=$ & - & - & - & 0 \\
\hline 82 & $8 / 5$ & 71 & - & - & - & - & - & - & - & - & - & - & 71 \\
\hline 83 & $8 / 5$ & 81 & - & - & - & $\overline{-}$ & $\overline{-}$ & $\overline{-}$ & $\overline{-}$ & - & - & $\overline{-}$ & 81 \\
\hline 84 & $11 / 5$ & 13 & $15 / 5$ & 88 & $19 / 5$ & 74 & - & - & - & - & - & - & 175 \\
\hline 85 & - & $\overline{-}$ & - & - & - & - & $\overline{-}$ & - & - & - & - & - & $\overline{0}$ \\
\hline 86 & $6 / 5$ & 39 & $\overline{-}$ & $\overline{-}$ & $\overline{-}$ & $\overline{-}$ & $\overline{-}$ & $\overline{-}$ & $\overline{-}$ & $\overline{-}$ & $\overline{-}$ & $\overline{-}$ & 39 \\
\hline 87 & $9 / 5$ & 85 & $\overline{-}$ & $=$ & $\overline{-}$ & - & - & - & - & - & - & $\overline{-}$ & 85 \\
\hline 88 & $9 / 5$ & 121 & $=$ & - & - & - & - & - & - & $\overline{-}$ & $\overline{-}$ & $\overline{-}$ & 121 \\
\hline 89 & $6 / 5$ & 98 & $12 / 5$ & 92 & - & $\overline{-}$ & - & - & - & - & - & - & 190 \\
\hline 90 & 715 & 113 & $14 / 5$ & 161 & $\overline{-}$ & $\overline{-}$ & $\overline{-}$ & $\overline{-}$ & - & - & $\overline{-}$ & - & 274 \\
\hline
\end{tabular}




\begin{tabular}{|c|c|c|c|c|c|c|c|c|c|c|c|c|c|}
\hline \multicolumn{14}{|c|}{ (cont.) Quadro 1} \\
\hline $\mathbf{N}^{\circ}$ 와 & $1^{2}$ Ovip & Quant. & $2^{\circ}$ Ovip & Quant. & $3^{*}$ Ovip & Quant. & 4" Ovip & Quant. & $5^{\circ}$ Ovip & Quant. & 6a Ovip & Quant. & Total \\
\hline 91 & - & - & $\overline{-}$ & $=$ & $\overline{-}$ & $\overline{-}$ & $=$ & - & - & - & $=$ & $=$ & 0 \\
\hline 92 & $9 / 5$ & 109 & $\overline{-}$ & - & $\overline{-}$ & $=$ & $\overline{-}$ & - & - & - & - & $=$ & 109 \\
\hline 93 & - & - & $=$ & $=$ & - & - & $=$ & $=$ & $=$ & - & $=$ & $=$ & 0 \\
\hline 94 & $7 / 5$ & 68 & $\overline{-}$ & $=$ & $\overline{-}$ & $\overline{-}$ & $=$ & - & $=$ & - & $=$ & - & 68 \\
\hline 95 & - & $=$ & $=$ & $=$ & = & - & $=$ & $=$ & - & - & $=$ & $=$ & 0 \\
\hline 96 & $7 / 5$ & 107 & $10 / 5$ & 59 & $\overline{-}$ & $\overline{-}$ & - & $\overline{-}$ & $\overline{-}$ & - & - & - & 166 \\
\hline 97 & $6 / 5$ & 79 & - & $\overline{-}$ & $\overline{-}$ & - & - & - & - & - & - & - & 79 \\
\hline 98 & $10 / 5$ & 62 & $=$ & $\bar{z}$ & $=$ & $\bar{z}+1+x+$ & $\bar{z}+x+1+$ & $\overline{-}$ & $\overline{-}$ & - & $\overline{-}$ & $=$ & 62 \\
\hline 99 & - & - & - & $=$ & $=$ & $=$ & $=$ & - & $=$ & $=$ & $=$ & $=$ & 0 \\
\hline 100 & $11 / 5$ & 84 & $15 / 5$ & 42 & $18 / 5$ & 90 & $\overline{-}$ & $\overline{-}$ & $\overline{-}$ & $\overline{-}$ & $\overline{-}$ & - & 216 \\
\hline
\end{tabular}


ANEXO 2 - Procedimento com o material de campo.
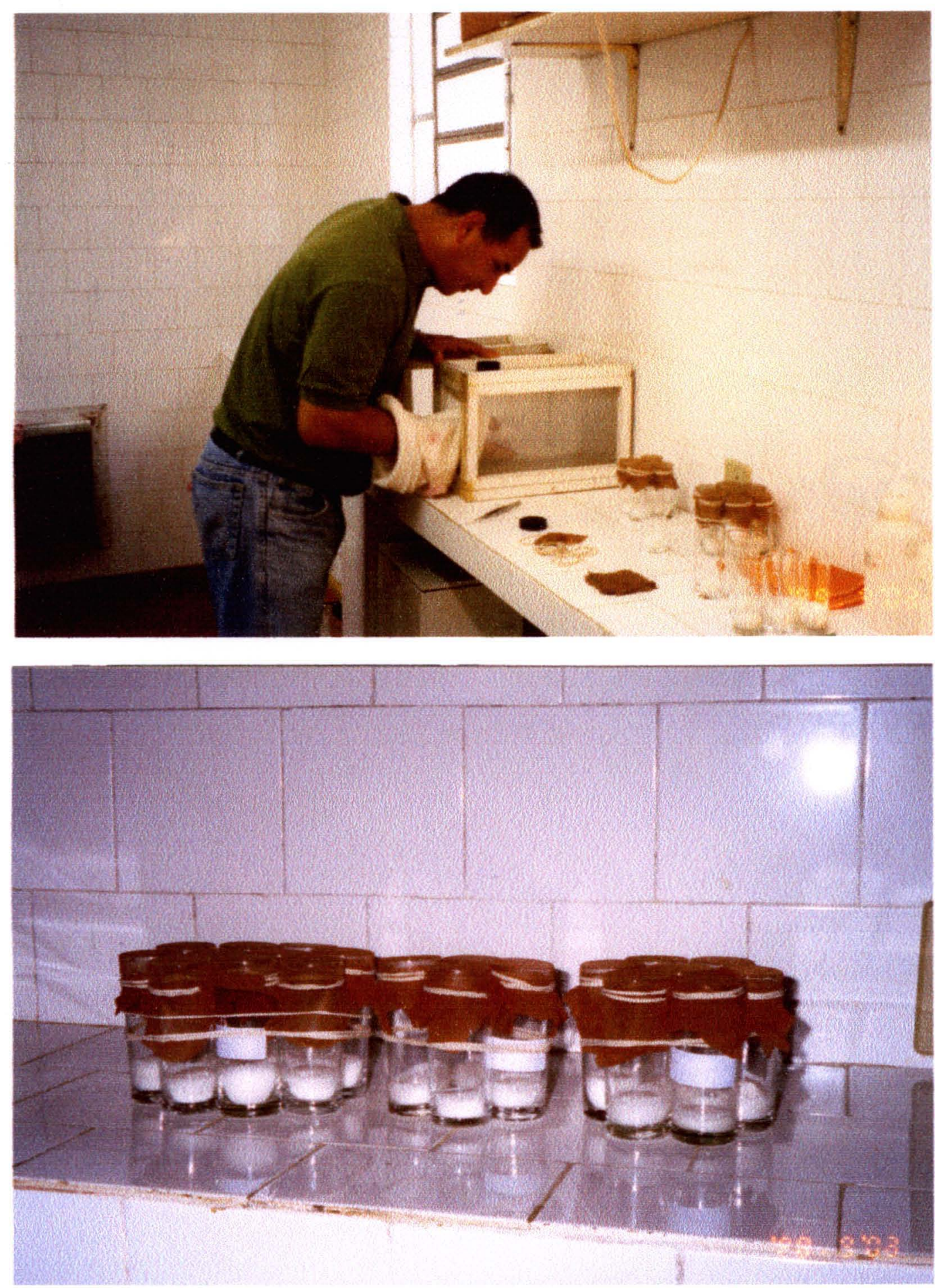

Figura 4: Triagem das fêmeas de Oc. scapularis coletadas em campo e individualizadas em Borrel Posto da USP em Pariquera-Açu, agosto de 2003. 